Supporting Information for

\title{
Blob-Based Predictions of Protein Folding Times from the Amino Acid Dependent Conformation of Polypeptides in Solution
}

\author{
Remi Casier* and Jean Duhamel*
}

Institute for Polymer Research, Waterloo Institute for Nanotechnology, Department of Chemistry, University of Waterloo, Waterloo, ON, N2L3G1, Canada

* To whom correspondence should be addressed

Corresponding authors: remi.casier@uwaterloo.ca and jduhamel@uwaterloo.ca 


\section{Table of Contents}

A] Preparation and characterization of a series of poly $(L$-lysine $)$ s randomly labeled with

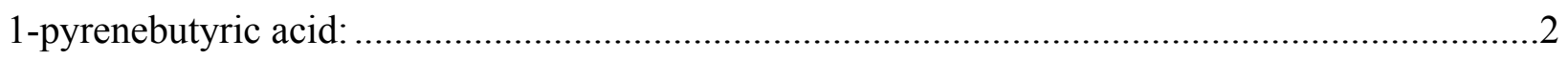

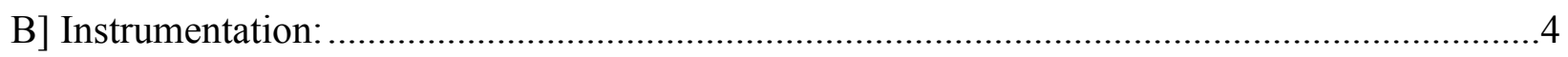

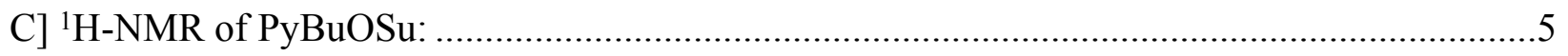

D] Steady state fluorescence spectra and their $I_{\mathrm{E}} / I_{\mathrm{M}}$ ratios of PyBu-PLL in DMSO: ....................6

E] Equations used to analyze the fluorescence decays of PyBu-PLL: .......................................6

F] Example of global-fit of the monomer and excimer decays of PyBu-PLL according to the FBM:

G] Parameters retrieved from the FBM of PyBu-PLL: .....................................................11

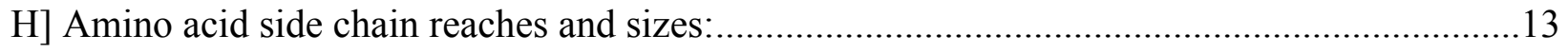

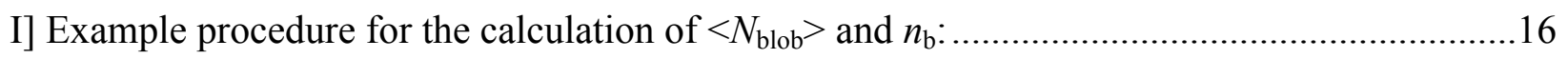

J] Additional discussion on the blob size calculations: ............................................................18

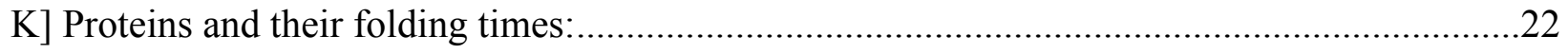

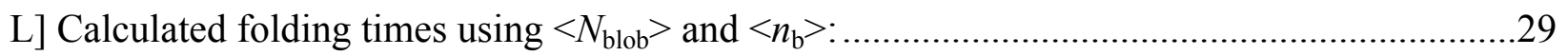

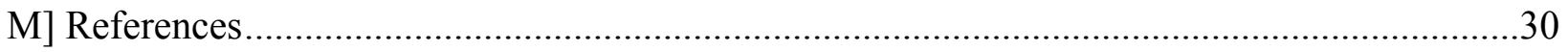




\section{A] Preparation and characterization of a series of poly $(L$-lysine $)$ s randomly labeled with 1-pyrenebutyric acid:}

Chemicals: Acetonitrile (ACN, Sigma, $\geq 99.9 \%$ ), dichloromethane (DCM, Sigma, $\geq 99.8 \%$ ), $N^{\prime}, N^{\prime}$-dicyclohexylcarbodiimide (DCC, Sigma, 99\%), dimethyl sulfoxide (DMSO, Sigma, $\geq 99.9 \%$ ), $N, N$-dimethylformamide (DMF, Sigma, $\geq 99.9 \%$ ), 2-propanol (isopropanol, Sigma, 99\%), $N$-hydroxysuccinimide (HOSu, Sigma, 98\%), $N, N$-diisopropylethylamine (DIPEA, Sigma, $\geq 99 \%$ ), poly( $L$-lysine) (PLL $\cdot \mathrm{HBr}$, Alamanda Polymers, $M_{\mathrm{n}}=165,100 \mathrm{~g} \cdot \mathrm{mol}^{-1}, D P=790, Ð=$ 1.06), and 1-pyrenebutyric acid (Sigma, 97\%) were used as received. Deionized water was obtained from a Biopure Series 4400 Single Pass Reverse Osmosis system.

1-Pyrenebutyric acid N-hydroxysuccinimide ester (PyBuOSu): 1-Pyrenebutyric acid (1.0 g, 3.5 mmol, 1 eq.) and HOSu ( $0.48 \mathrm{~g}, 4.2 \mathrm{mmol}, 1.2$ eq.) were dissolved in a solution of DCM (60 mL) and ACN (20 mL). DCC (0.83 g, $4.0 \mathrm{mmol}, 1.2 \mathrm{eq}$.) was added and the solution was left to stir overnight in the dark. The reaction was filtered to remove the urea side product and condensed to $\sim 25 \mathrm{~mL}$ on a rotary evaporator. The solution was then filtered again to remove additional urea that had precipitated. The solution was condensed to $\sim 10 \mathrm{~mL}$ and isopropanol $(60 \mathrm{~mL})$ was added to precipitate $\mathrm{PyBuOSu}$. The PyBuOSu product was then collected by suction filtration. The brown solid was dissolved in DCM $(10 \mathrm{~mL})$ and precipitated in isopropanol $(60 \mathrm{~mL})$ twice more. The solid was dried under vacuum to yield PyBuOSu (0.79 g, $2.0 \mathrm{mmol}, 59 \%$ yield). The ${ }^{1} \mathrm{H}$ NMR spectrum of PyBuOSu is provided as Figure S1 in the Supporting Information (SI).

1-Pyrenebutyric acid-labeled poly(L-lysine) (PyBu-PLL): The PyBu-PLL samples were prepared from the hydrobromide salt of poly $(L$-lysine $)(\mathrm{P} L \mathrm{~L} \cdot \mathrm{HBr})$. An example preparation of a $\mathrm{PyBu}-\mathrm{P} L \mathrm{~L}$ sample, where $4.4 \mathrm{~mol} \%$ of the lysines were labeled with pyrene, is described. $\mathrm{P} L \mathrm{~L} \cdot \mathrm{HBr}(34.2 \mathrm{mg}$, $0.16 \mathrm{mmol}$ Lys) was added to a stirring solution of DIPEA ( $32 \mu \mathrm{L}, 1.1$ eq. per Lys) and DMSO (5 
$\mathrm{mL})$. Once $\mathrm{P} L \mathrm{~L} \cdot \mathrm{HBr}$ had dissolved, a solution of PyBuOSu in DMSO $\left(0.34 \mathrm{~mL}, 10.2 \mathrm{mg} \cdot \mathrm{mL}^{-1}\right.$, 0.05 eq. per Lys) was added. The stirring solution was left to stir overnight in the dark. PyBu-PLL was purified by dialysis using an $8 \mathrm{kDa}$ molecular weight cutoff regenerated cellulose membrane. The PyBu-PLL solution was dialyzed against successive solutions of DMF, a series of 2:1, 1:1, 1:3 DMF:water mixtures, and lastly water acidified with $\mathrm{HCl}(\mathrm{pH} \sim 5)$. The hydrochloride salt of PyBu-PLL was then freeze dried and stored at $-20^{\circ} \mathrm{C}$ until it was used for fluorescence measurements.

Pyrene content determination: The pyrene content of the PyBu-PLL samples was determined with Equation S1. In Equation S1, $x$ is the molar fraction of lysine residues bearing pyrene, $M_{\mathrm{Lys}}$ is the molar mass of the hydrochloride salt of a lysine residue $\left(=164.63 \mathrm{~g} \cdot \mathrm{mol}^{-1}\right), M_{\mathrm{Py}}$ is the molar mass of a lysine bearing a pyrenyl label $\left(=370.45 \mathrm{~g} \cdot \mathrm{mol}^{-1}\right)$, and $\lambda_{\mathrm{Py}}$ is the number of moles of pyrene per mass of PyBu-PLL. $\lambda_{\text {Py }}$ was determined by measuring the absorbance of a PyBu-PLL solution in DMSO with a known mass concentration. To this end, $10 \mathrm{mg}$ of lyophilized PyBu-PLL was dissolved in $5 \mathrm{~mL}$ of DMSO. After sonicating for 30 minutes, an aliquot of the solution was diluted and transferred to a $1.0 \mathrm{~cm}$ pathlength cell for UV-Vis absorption measurements. The molar concentration of pyrene was determined using the Beer-Lambert law at the absorbance peak maximum of pyrene at $346 \mathrm{~nm}$ with the molar absorptivity coefficient of 1-pyrenebutyric acid used as a model compound in $\operatorname{DMSO}\left(\varepsilon=41,400 \mathrm{M}^{-1} \cdot \mathrm{cm}^{-1}\right) \cdot{ }^{1}$

$$
x=\frac{M_{L y s}}{\lambda_{P y}{ }^{-1}+M_{L y s}-M_{P y}}
$$




\section{B] Instrumentation:}

UV-Vis absorbance measurements: The absorption spectra were acquired with a Varian Cary 100 Bio spectrophotometer using a $1.0 \mathrm{~cm}$ quartz UV-Vis absorption cell. A background correction for the solvent was applied to each spectrum.

Steady-state fluorescence (SSF): The steady-state fluorescence spectra were acquired on a Horiba QM-400 spectrofluorometer equipped with a xenon arc lamp. Samples were prepared by diluting a solution of PyBu-PLL in DMSO such that the concentration of pyrene was equal to $2.4 \mu \mathrm{M}$. A small aliquot $(10 \mu \mathrm{L})$ of $1 \mathrm{M} \mathrm{HCl}$ was added to a $4 \mathrm{~mL}$ solution of PyBu-PLL to ensure that the lysines were protonated. The solution was then sonicated for 15 minutes and outgassed with nitrogen (Praxair, N4.0) to remove oxygen. The fluorescence cell was then sealed and the SSF spectra acquired using an excitation wavelength of $346 \mathrm{~nm}$. The excitation and emission slit widths were set to $1 \mathrm{~nm}$. The emission was monitored from 350 to $600 \mathrm{~nm}$ in $1 \mathrm{~nm}$ increments with a scanning rate of $10 \mathrm{~nm} \cdot \mathrm{s}^{-1}$. The fluorescence intensity of the pyrene excimer $\left(I_{\mathrm{E}}\right)$ and monomer $\left(I_{\mathrm{M}}\right)$ were determined by integrating the intensity of the fluorescence spectra from 500 to $530 \mathrm{~nm}$ and from 376 to $382 \mathrm{~nm}$, respectively. Dividing $I_{\mathrm{E}}$ by $I_{\mathrm{M}}$ yielded the $I_{\mathrm{E}} / I_{\mathrm{M}}$ ratio which was used to quantify the efficiency of pyrene excimer formation (PEF).

Time-resolved fluorescence (TRF): The fluorescence decays of PyBu-PLL were acquired with an IBH TC-SPC fluorometer equipped with a NanoLED-340 laser using the same samples as for the SSF measurements. The monomer and excimer fluorescence decays were acquired over 1,024 channels using a time-per-channel of $1.02 \mathrm{~ns} \cdot \mathrm{ch}^{-1}$. The monomer decay was acquired at $378 \mathrm{~nm}$ to a decay maximum of at least 40,000 counts. The excimer decay was acquired at $510 \mathrm{~nm}$ to a decay maximum of at least 20,000 counts. A 370 or $490 \mathrm{~nm}$ long pass filter was placed at the entrance of the emission monochromator to minimize stray light and scattering photons from 
reaching the detector during the acquisition of the monomer and excimer TRF decays, respectively. The instrument response function was acquired using a LUDOX dispersion in water for deconvolution of the fluorescence decays.

\section{C] ${ }^{1} \mathrm{H}-\mathrm{NMR}$ of PyBuOSu:}

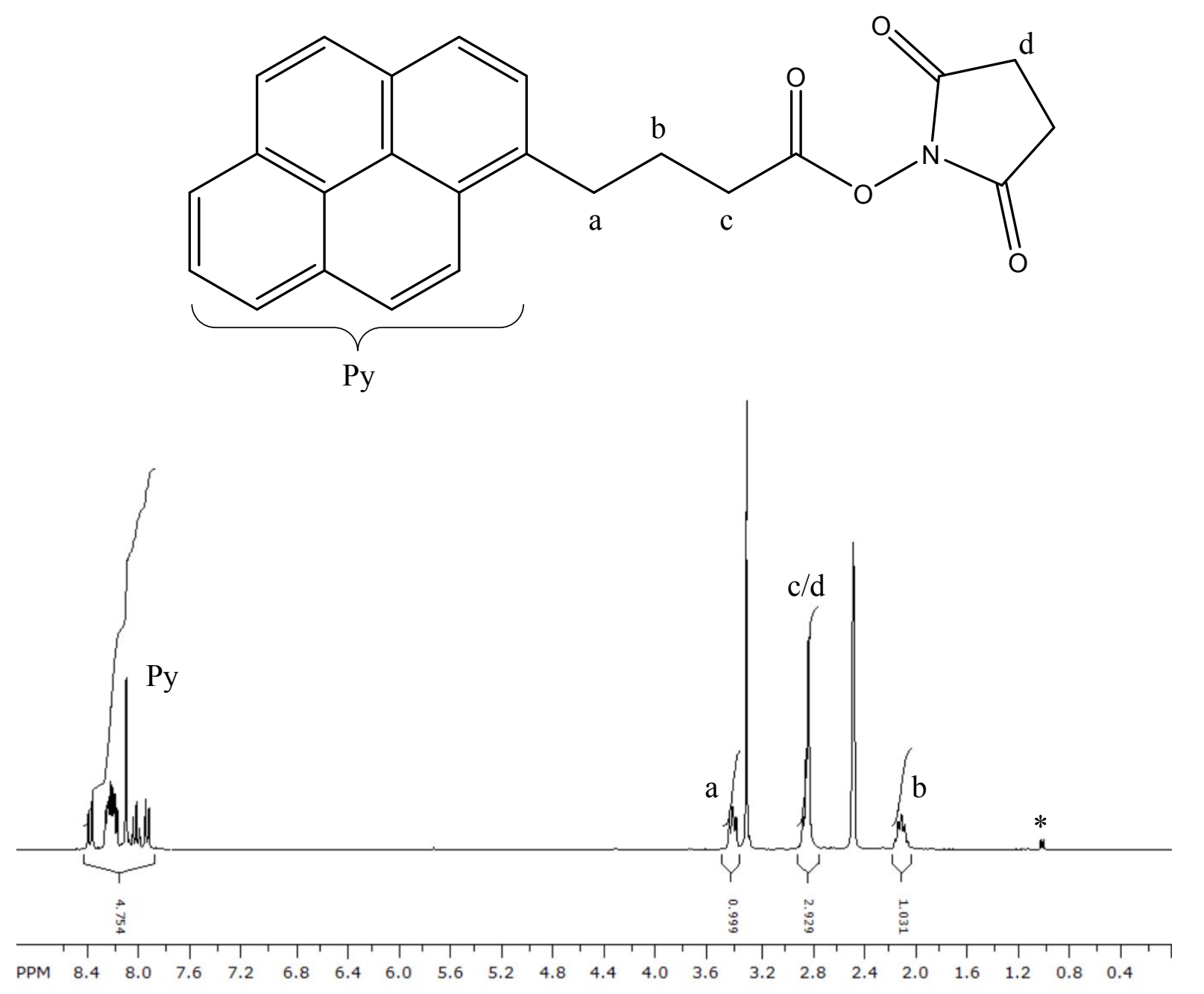

Figure S1. ${ }^{1} \mathrm{H}-\mathrm{NMR}$ spectrum of PyBuOSu. $300 \mathrm{MHz}, \mathrm{d}_{6}$-DMSO: $\delta=8.4-7.9(9 \mathrm{H}, \mathrm{m}), 3.41(2 \mathrm{H}$, t), $2.9-2.8(6 \mathrm{H}, \mathrm{m})$ and $2.10(2 \mathrm{H}, \mathrm{p})$. The peak marked with an asterisk $(*)$ is from residual isopropanol (1.04 ppm). Residual water (3.31 ppm) and solvent (2.47 ppm) peaks are also present. 
D] Steady state fluorescence spectra and their $I_{E} / I_{M}$ ratios of PyBu-PLL in DMSO:
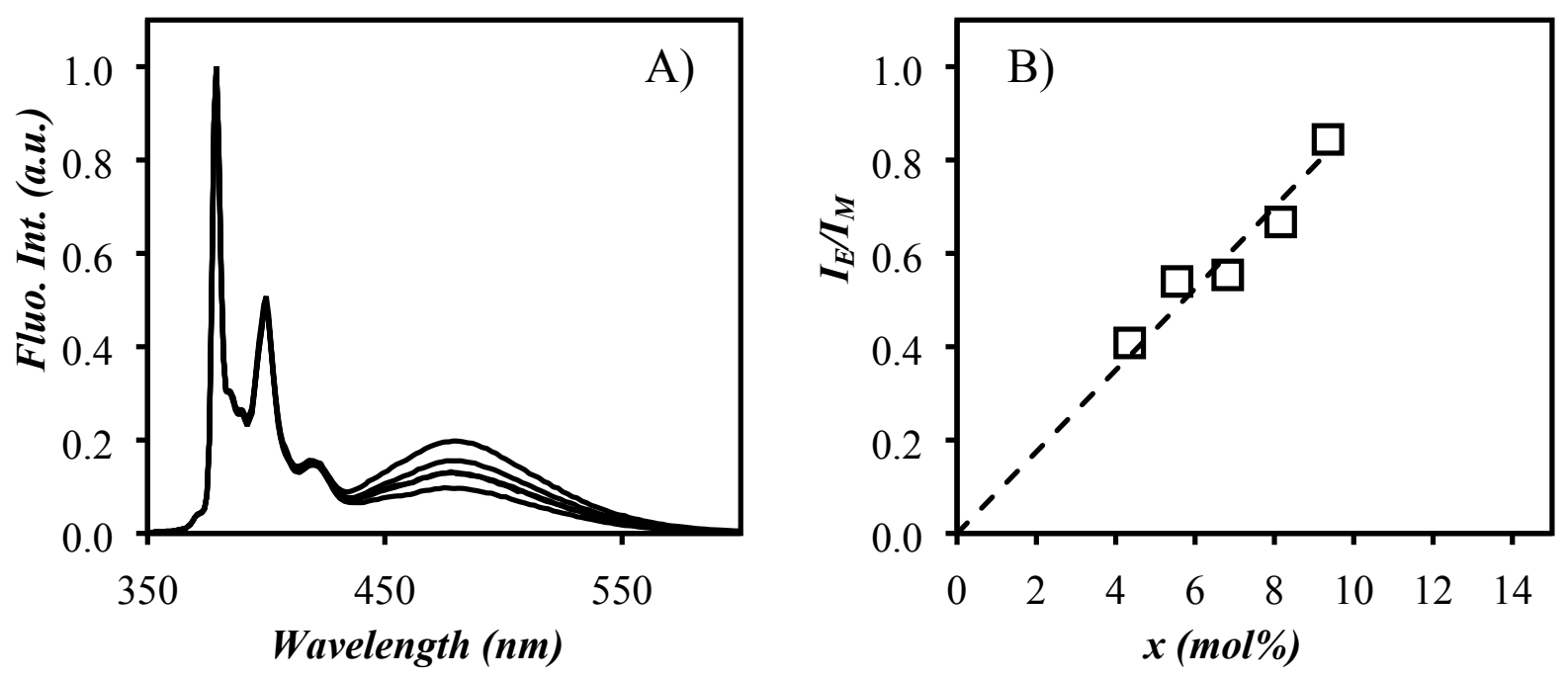

Figure S2. A) Steady state fluorescence spectra of $\mathrm{PyBu}-\mathrm{P} L \mathrm{~L}$ in DMSO and B) $I_{\mathrm{E}} / I_{\mathrm{M}}$ ratios of PyBu-P $L L$ in DMSO as a function of pyrene content. $\lambda_{\mathrm{ex}}=344 \mathrm{~nm},[\mathrm{Py}]=2.4 \times 10^{-6} \mathrm{M}$

E] Equations used to analyze the fluorescence decays of PyBu-PLL:

The monomer and excimer decays of the PyBu-PLLs were fit with Equations S2 and S3.

$$
\begin{aligned}
{\left[P y^{*}\right]_{(t)} } & =\left[P y_{\text {diff }}^{*}\right]_{(t)}+\left[P y_{k 2}^{*}\right]_{(t)}+\left[P y_{\text {free }}^{*}\right]_{(t)}=\left[P y_{\text {diff }}^{*}\right]_{o} \exp \left(-\left(A_{2}+\frac{1}{\tau_{M}}\right) t-A_{3}\left(1-\exp \left(-A_{4} t\right)\right)\right) \\
& +\left(\left[P y_{k 2}^{*}\right]_{o}+\left[P y_{\text {diff }}^{*}\right]_{o} e^{-A_{3}} \sum_{i=0}^{\infty} \frac{A_{3}^{i}}{i !} \frac{A_{2}+i A_{4}}{A_{2}+i A_{4}-k_{2}}\right) \exp \left(-\left(k_{2}+\frac{1}{\tau_{M}}\right) t\right) \\
& -\left[P y_{\text {diff }}^{*}\right]_{o} e^{-A_{3}} \sum_{i=0}^{\infty} \frac{A_{3}^{i}}{i !} \frac{A_{2}+i A_{4}}{A_{2}+i A_{4}-k_{2}} \exp \left(-\left(A_{2}+i A_{4}+\frac{1}{\tau_{M}}\right) t\right) \\
& \left.+\left[P y_{\text {free }}^{*}\right]_{o} \exp \left(-\frac{t}{\tau_{M}}\right)\right]
\end{aligned}
$$




$$
\begin{aligned}
& {\left[E^{*}\right]_{(t)}=\left[E 0^{*}\right]_{(t)}+\left[D^{*}\right]_{(t)}+\left[E S^{*}\right]_{(t)}=k_{2}\left(\left(\left[P y_{k 2}^{*}\right]_{o}+\left[P y_{\text {diff }}^{*}\right]_{o} e^{-A_{3}} \sum_{i=0}^{\infty} \frac{A_{3}^{i}}{i !} \frac{A_{2}+i A_{4}}{A_{2}+i A_{4}-k_{2}}\right)\right.} \\
& \times \frac{\exp \left(-\frac{t}{\tau_{E 0}}\right)-\exp \left(-\left(k_{2}+\frac{1}{\tau_{M}}\right) t\right)}{k_{2}+\frac{1}{\tau_{M}}-\frac{1}{\tau_{E 0}}} \\
& \left.+\left[P y_{\text {diff }}^{*}\right]_{0} e^{-A_{3}} \sum_{i=0}^{\infty} \frac{A_{3}^{i}}{i !} \frac{A_{2}+i A_{4}}{A_{2}+i A_{4}-k_{2}} \frac{\exp \left(-\left(A_{2}+i A_{4}+\frac{1}{\tau_{M}}\right) t\right)-\exp \left(-\frac{t}{\tau_{E 0}}\right)}{A_{2}+i A_{4}+\frac{1}{\tau_{M}}-\frac{1}{\tau_{E 0}}}\right) \\
& +k_{2}\left(\left(\left[P y_{k 2}^{*}\right]_{o}+\left[P y_{\text {diff }}^{*}\right]_{o} e^{-A_{3}} \sum_{i=0}^{\infty} \frac{A_{3}^{i}}{i !} \frac{A_{2}+i A_{4}}{A_{2}+i A_{4}-k_{2}}\right) \times \frac{\exp \left(-\frac{t}{\tau_{D}}\right)-\exp \left(-\left(k_{2}+\frac{1}{\tau_{M}}\right) t\right)}{k_{2}+\frac{1}{\tau_{M}}-\frac{1}{\tau_{D}}}\right. \\
& \left.+\left[P y_{\text {diff }}^{*}\right]_{O} e^{-A_{3}} \sum_{i=0}^{\infty} \frac{A_{3}^{i}}{i !} \frac{A_{2}+i A_{4}}{A_{2}+i A_{4}-k_{2}} \frac{\exp \left(-\left(A_{2}+i A_{4}+\frac{1}{\tau_{M}}\right) t\right)-\exp \left(-\frac{t}{\tau_{D}}\right)}{A_{2}+i A_{4}+\frac{1}{\tau_{M}}-\frac{1}{\tau_{D}}}\right) \\
& +\left[E 0^{*}\right]_{o} \times \exp \left(-\frac{t}{\tau_{E 0}}\right)+\left[D^{*}\right]_{o} \times \exp \left(-\frac{t}{\tau_{D}}\right)+\left[E S^{*}\right]_{o} \times \exp \left(-\frac{t}{\tau_{S}}\right)
\end{aligned}
$$

In Equations $\mathrm{S} 2$ and $\mathrm{S} 3$, the parameters $A_{2}, A_{3}$, and $A_{4}$ are given in Equations S4.a-c.

$$
\begin{array}{r}
A_{2}=<n>\times \frac{k_{\text {blob }} k_{e}[\text { blob }]}{k_{b l o b}+k_{e}[\text { blob }]} \\
A_{3}=<n>\times\left(\frac{k_{\text {blob }}}{k_{\text {blob }}+k_{e}[\text { blob] }]}\right)^{2}
\end{array}
$$




$$
A_{4}=k_{b l o b}+k_{e}[b l o b]
$$

In Equations $\mathrm{S} 2-\mathrm{S} 4$, the parameters $k_{\mathrm{blob}}, k_{\mathrm{e}}[b l o b]$, and $<n>$ represent the rate constant for the diffusive encounters between two structural units bearing a pyrenyl label, the product of the rate constant for exchange $\left(k_{\mathrm{e}}\right)$ of ground-state pyrene between blobs and the local blob concentration, and the average number of pyrenyl labels inside a blob, respectively. Analysis of the fluorescence decays assumes that five pyrene species are present in solution, namely those pyrenes that are isolated and cannot form excimer $\left(P y_{\text {free }}{ }^{*}\right)$, are subject to the diffusive motion of the structural units they are attached to $\left(P y_{\text {diffE } 0} *\right.$ or $P y_{\text {diffD }} *$ depending on whether they form a well $\left(E 0^{*}\right)$ or poorly $\left(D^{*}\right)$ stacked dimer, respectively), or re-arrange quickly to form an excimer $E 0^{*}$ or $D^{*}$ with a rate constant $k_{2}\left(P y_{\mathrm{k} 2 \mathrm{E} 0} *\right.$ and $P y_{\mathrm{k} 2 \mathrm{E} 0} *$, respectively). Finally, a short-lived decay is often observed in the excimer fluorescence decays and is attributed to a residual contribution from short-lived excimer $\left(E S^{*}\right)$ or light scattering. It is typically not taken into account in the calculation of the molar fractions of the different pyrene species. Analysis of the monomer fluorescence decays with Equation S2 yields the molar fractions $f_{\mathrm{Mdiff}}, f_{\mathrm{Mk} 2}$, and $f_{\mathrm{Mfree}}$ of the pyrene species $P y_{\text {diff }}{ }^{*}, P y_{\mathrm{k} 2}{ }^{*}$, and $P y_{\text {free }}{ }^{*}$, where the M-subscript indicates that these pyrene species were detected in the monomer fluorescence decays. Analysis of the excimer fluorescence decays with Equation S3 yields the molar fractions $f_{\mathrm{EdiffE} 0}, f_{\mathrm{EdiffD}}, f_{\mathrm{Ek} 2 \mathrm{E} 0}, f_{\mathrm{Ek} 2 \mathrm{D}}, f_{\mathrm{EE} 0}, f_{\mathrm{ED}}$, and $f_{\mathrm{ES}}$ of the pyrene species $P y_{\text {diffE0 }}{ }^{*}, P y_{\text {diffD }} *, P y_{\mathrm{k} 2 \mathrm{E} 0^{*}}{ }^{*} P y_{\mathrm{k} 2 \mathrm{D}}{ }^{*}, E 0^{*}, D^{*}$, and $E S^{*}$, where the E-subscript indicates that these pyrene species were detected in the excimer fluorescence decays. The molar fractions $f_{\mathrm{Mdiff}}, f_{\mathrm{Mk} 2}$, $f_{\mathrm{Mfree}}, f_{\mathrm{EdiffE} 0}, f_{\mathrm{EdiffD}}, f_{\mathrm{Ek} 2 \mathrm{E} 0}, f_{\mathrm{Ek} 2 \mathrm{D}}, f_{\mathrm{EE} 0}, f_{\mathrm{ED}}$, and $f_{\mathrm{ES}}$ obtained from the monomer or the excimer fluorescence decays were used to determine the molar fractions $f_{\text {diff, }} f_{\mathrm{k} 2}, f_{\text {free }}, f_{\mathrm{E} 0}$, and $f_{\mathrm{D}}$ whose expressions are given in Equations S5 - S9. The additional lifetime $\tau_{\mathrm{S}}=3.5 \mathrm{~ns}$ and its 
corresponding contribution to the excimer decay $\left[E S^{*}\right]_{0}$ was added to account for the presence of a short lifetime present in the excimer decay which was attributed to light scattering.

$$
\begin{aligned}
& f_{\text {diff }}=\frac{1}{1+\frac{f_{\text {Mk2 } 2}+f_{\text {Mfree }}}{f_{\text {Mdiff }}}+\frac{f_{E E 0}+f_{E D}}{f_{E d i f f E 0}+f_{\text {Ediff } D}}} \\
& f_{k 2}=f_{\text {diff }} \times \frac{f_{M k 2}}{f_{\text {Mdiff }}}=f_{\text {diff }} \times \frac{f_{E k 2 E 0}+f_{E k 2 D}}{f_{E d i f f E 0}+f_{\text {Ediff } D}} \\
& f_{\text {free }}=f_{\text {diff }} \times \frac{f_{\text {Mfree }}}{f_{\text {Mdiff }}} \\
& f_{E 0}=f_{\text {diff }} \times \frac{f_{E E 0}}{f_{E \text { diffE } 0}+f_{\text {EdiffD }}} \\
& f_{D}=f_{\text {diff }} \times \frac{f_{E D}}{f_{E \text { diffE } 0}+f_{\text {EdiffD }}}
\end{aligned}
$$

$N_{\text {blob }}$ was calculated using Equation S10, where $x$ is molar fraction of lysines bearing a pyrene label.

$$
N_{\text {blob }}=\frac{<n>}{x}\left(1-f_{\text {Mfree }}\right)
$$


F] Example of global-fit of the monomer and excimer decays of $P y B u-P L L$ according to the FBM:
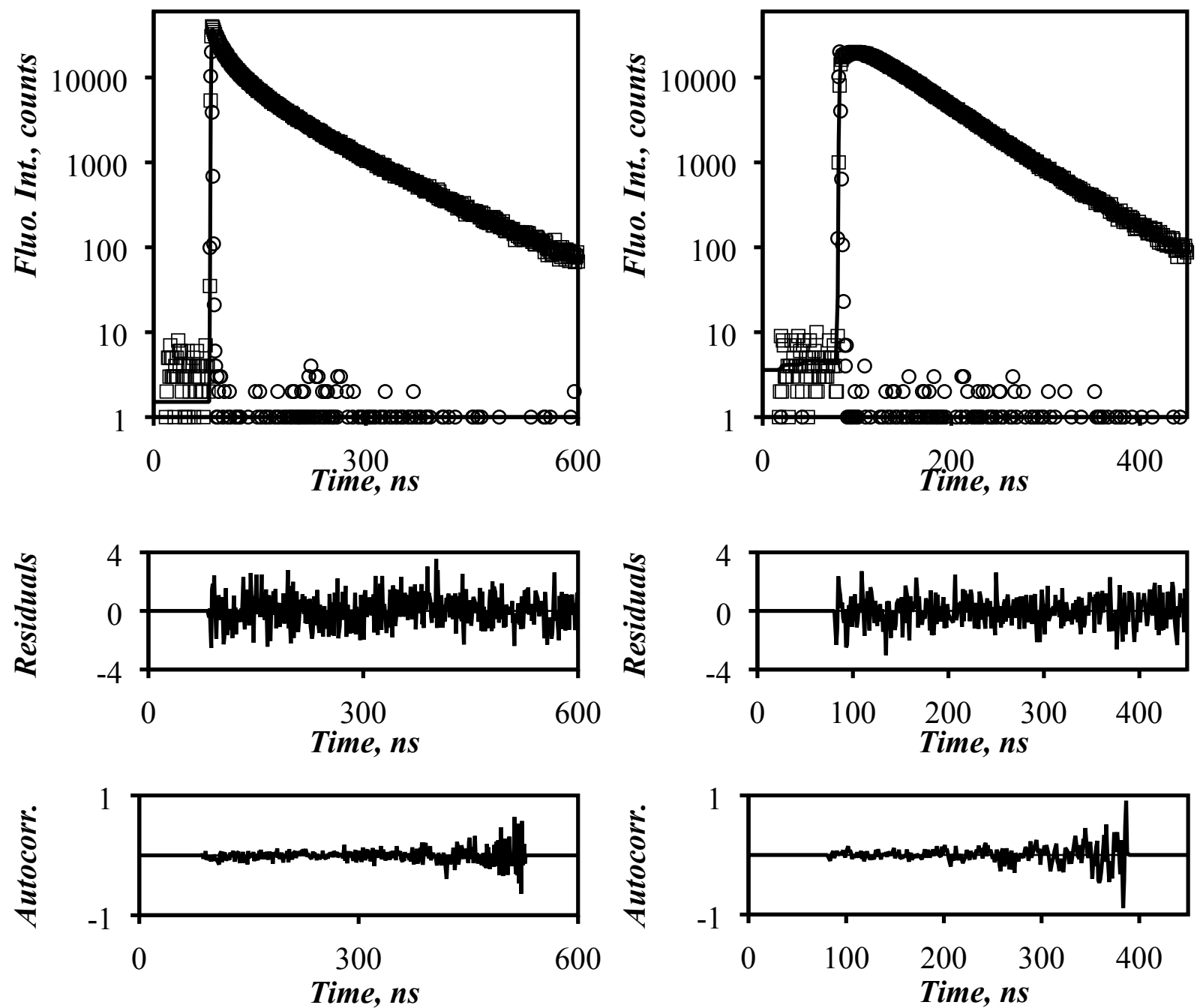

Figure S3. Monomer (left, $\lambda_{\mathrm{em}}=378 \mathrm{~nm}$ ) and excimer (right, $\lambda_{\mathrm{em}}=510 \mathrm{~nm}$ ) fluorescence decays ( $\square$ ) of PyBu-PLL $(x=9.4 \mathrm{~mol} \%)$ in DMSO. The instrument response function $(\circ)$ and the fit of the global analysis of the FBM (-) are overlaid with the fluorescence decays. $\lambda_{\mathrm{ex}}=344 \mathrm{~nm}$, [Py] $=2.4 \times 10^{-6}$ M. $\chi^{2}=1.15$. 


\section{G] Parameters retrieved from the FBM of PyBu-PLL:}

Table S1. Parameters retrieved using the FBM analysis of the pyrene monomer decays of PyBu$\mathrm{P} L \mathrm{~L}$ in acidified DMSO.

\begin{tabular}{|c|c|c|c|c|c|c|c|c|c|}
\hline Polypeptide & $\begin{array}{c}x \\
(\mathrm{~mol} \%)\end{array}$ & $\begin{array}{c}k_{2} \\
\left(\mathrm{~ns}^{-1}\right)\end{array}$ & $f_{\mathrm{Mk} 2}$ & $\begin{array}{c}k_{\mathrm{e}}[\text { blob] } \\
\left(\mu \mathrm{s}^{-1}\right)\end{array}$ & $f_{\text {Mdiff }}$ & $\begin{array}{c}k_{\mathrm{blob}} \\
\left(\mu \mathrm{s}^{-1}\right)\end{array}$ & $<n>$ & $f_{\text {Mfree }}$ & $\chi^{2}$ \\
\hline \multirow{3}{*}{$\begin{array}{c}\text { PyBu-PLL } \\
\tau_{\mathrm{M}}=135 \mathrm{~ns}\end{array}$} & 4.4 & 0.24 & 0.32 & 3.9 & 0.49 & 20.7 & 1.03 & 0.19 & 1.14 \\
\cline { 2 - 10 } & 5.5 & 0.24 & 0.33 & 7.9 & 0.61 & 24.3 & 1.18 & 0.05 & 1.15 \\
\cline { 2 - 10 } & 6.8 & 0.24 & 0.31 & 5.0 & 0.60 & 19.0 & 1.28 & 0.09 & 1.15 \\
\cline { 2 - 10 } & 9.4 & 0.24 & 0.31 & 6.9 & 0.66 & 19.9 & 1.32 & 0.03 & 1.16 \\
\cline { 2 - 10 } & 0.24 & 0.34 & 5.4 & 0.63 & 20.9 & 1.66 & 0.03 & 1.15 \\
\hline
\end{tabular}

Table S2. Parameters retrieved using the FBM analysis of the pyrene excimer decays of PyBu$\mathrm{P} L \mathrm{~L}$ in acidified DMSO.

\begin{tabular}{|c|c|c|c|c|c|c|c|c|c|c|c|}
\hline Polypeptide & $\begin{array}{c}x \\
(\mathrm{~mol} \%)\end{array}$ & $f_{\mathrm{Ek} 2}$ & $\begin{array}{c}\tau_{\mathrm{E} 0} \\
(\mathrm{~ns})\end{array}$ & $f_{\text {EdiffE } 0}$ & $f_{\mathrm{EE} 0}$ & $\begin{array}{c}\tau_{D} \\
(\mathrm{~ns})\end{array}$ & $f_{\mathrm{EdiffD}}$ & $f_{\mathrm{ED}}$ & $\begin{array}{c}\tau_{\mathrm{S}} \\
(\mathrm{ns})\end{array}$ & $f_{\mathrm{S}}$ & $\chi^{2}$ \\
\hline \multirow{3}{*}{$\begin{array}{c}\text { PyBu-PLL } \\
\tau_{\mathrm{M}}=135 \mathrm{~ns}\end{array}$} & 4.4 & 0.27 & 33.4 & 0.16 & 0.03 & 45.2 & 0.25 & 0.00 & 3.5 & 0.29 & 1.14 \\
\cline { 2 - 12 } & 5.5 & 0.22 & 37.0 & 0.19 & 0.10 & 38.4 & 0.21 & 0.05 & 3.5 & 0.24 & 1.15 \\
\cline { 2 - 12 } & 6.8 & 0.26 & 37.8 & 0.15 & 0.03 & 54.4 & 0.30 & 0.00 & 3.5 & 0.26 & 1.15 \\
\cline { 2 - 11 } & 9.2 & 0.23 & 40.6 & 0.18 & 0.00 & 41.7 & 0.30 & 0.10 & 3.5 & 0.20 & 1.16 \\
\hline
\end{tabular}


Table S3. Fraction of pyrene species calculated using parameters retrieved from the FBM analysis of PyBu-PLL in acidified DMSO.

\begin{tabular}{|c|c|c|c|c|c|c|c|c|c|c|}
\hline Polypeptide & $\begin{array}{c}x \\
(\mathrm{~mol} \%)\end{array}$ & $f_{\mathrm{k} 2}$ & $f_{\text {diffe } 0}$ & $f_{\text {diffD }}$ & $f_{\text {diff }}$ & $f_{\mathrm{E} 0}$ & $f_{\mathrm{D}}$ & $f_{\text {agg }}$ & $f_{\text {free }}$ & $\chi^{2}$ \\
\hline \multirow{3}{*}{$\begin{array}{c}\text { PyBu-PLL } \\
\tau_{\mathrm{M}}=135 \mathrm{~ns}\end{array}$} & 4.4 & 0.31 & 0.18 & 0.29 & 0.47 & 0.04 & 0.00 & 0.04 & 0.19 & 1.14 \\
\cline { 2 - 11 } & 5.5 & 0.27 & 0.23 & 0.27 & 0.50 & 0.12 & 0.06 & 0.18 & 0.04 & 1.15 \\
\cline { 2 - 11 } & 6.8 & 0.30 & 0.19 & 0.39 & 0.58 & 0.03 & 0.00 & 0.04 & 0.08 & 1.15 \\
\cline { 2 - 11 } & 8.2 & 0.28 & 0.21 & 0.36 & 0.57 & 0.00 & 0.12 & 0.12 & 0.03 & 1.16 \\
\cline { 2 - 11 } & 9.4 & 0.28 & 0.12 & 0.41 & 0.53 & 0.00 & 0.16 & 0.16 & 0.03 & 1.15 \\
\hline
\end{tabular}




\section{H] Amino acid side chain reaches and sizes:}

Table S4. List of the common 20 amino acids, their side chain reach and size, $N(\mathrm{SCR})$, and $f_{\mathrm{b}}(\mathrm{SCS})$ values. $N(\mathrm{SCR})$ and $f_{\mathrm{b}}(\mathrm{SCS})$ were calculated using Figures $7 \mathrm{~A}$ and $\mathrm{B}$, respectively, in the main text.

\begin{tabular}{|c|c|c|c|c|c|}
\hline Amino Acid & Structure & $\begin{array}{c}\text { Side Chain } \\
\text { Reach (SCR) }\end{array}$ & $N(\mathrm{SCR})$ & $\begin{array}{l}\text { Side Chain } \\
\text { Size (SCS) }\end{array}$ & $f_{\mathrm{b}}(\mathrm{SCS})$ \\
\hline Glycine & & 1 & 0.45 & 0 & 2.16 \\
\hline Alanine & & 2 & 0.89 & 1 & 1.46 \\
\hline Cysteine & & 3 & 1.34 & 2 & 1.26 \\
\hline Serine & & 3 & 1.34 & 2 & 1.26 \\
\hline Proline & & 3 & 1.34 & 3 & 1.14 \\
\hline Threonine & & 3 & 1.34 & 3 & 1.14 \\
\hline Valine & & 3 & 1.34 & 3 & 1.14 \\
\hline Isoleucine & & 3 & 1.78 & 4 & 1.06 \\
\hline Aspartic acid & & 3 & 1.34 & 4 & 1.06 \\
\hline
\end{tabular}




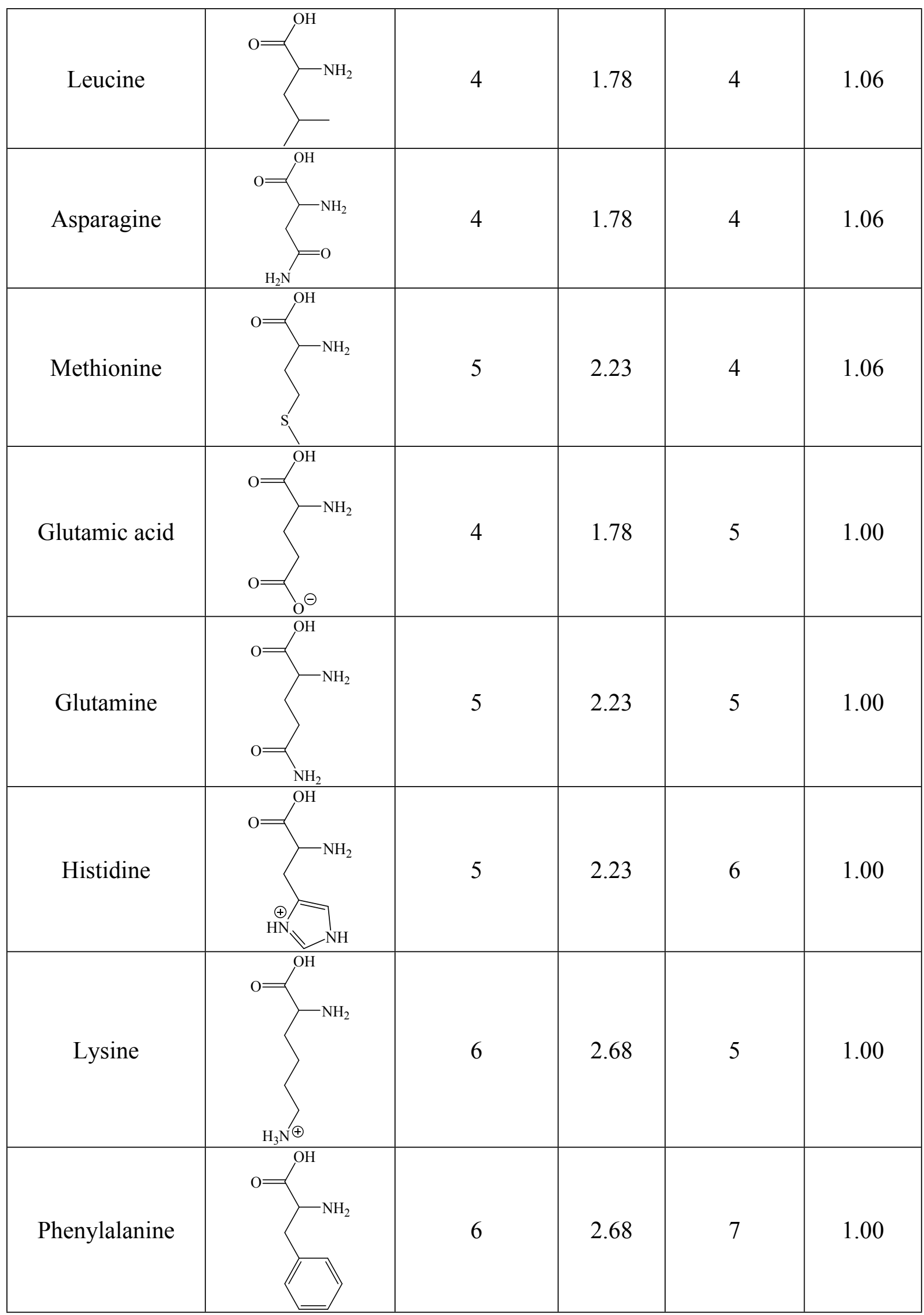




\begin{tabular}{|c|c|c|c|c|c|}
\hline Arginine & & 7 & 3.12 & 7 & 1.00 \\
\hline Tyrosine & & 7 & 3.12 & 8 & 1.00 \\
\hline Tryptophan & & 7 & 3.12 & 10 & 1.00 \\
\hline
\end{tabular}




\section{I] Example procedure for the calculation of $<N_{\text {blob }}>$ and $n_{\mathrm{b}}$ :}

The $N_{0}{ }^{1}, N_{0} \mathrm{r}$, and $N_{\text {blob }}$ values for each $a a$ in the sequence of the C-terminal $\beta$-hairpin of protein $\mathrm{G}$ (residues 41 - 56; protein data bank (PDB) code: 1PGB) is provided in Table S5. A depiction of $N_{0}^{1}, N_{0} \mathrm{r}$, and $N_{\text {blob }}$ is given as Figure 8 in the main text. The values in Table S5 were then used to determine $<N_{\text {blob }}>$ and $n_{\mathrm{b}}$ for the protein according to the procedure outlined in the main text and discussed in more detail hereafter.

Table S5. Example procedure for determining a proteins $N_{\text {blob }}$ and $n_{\mathrm{b}}$ values. The $N_{0}{ }^{1}, N_{0} \mathrm{r}$, and $N_{\text {blob }}$ values calculated for each $a a$ in the sequence of the $\mathrm{C}$-terminal $\beta$-hairpin of protein $\mathrm{G}$ (residues 41 - 56, PDB code 1PGB). ${ }^{2}$ The protein is divided into blobs based on the aa $N_{\text {blob }}$ values. In this example, the protein is divided into two blobs, one generated by tyrosine (Y) at position 5 and the other by valine (V) at position 14 . The protein contains $n_{\mathrm{b}}=2$ blobs with an average $N_{\text {blob }}\left(<N_{\text {blob }}>\right)$ of $9.5(=(12+7) / 2)$. This combination of blobs is denoted by $[5,14]$ since the sequence is contained in two blobs, one located at position 5 and the other at position 14 .

\begin{tabular}{|c|c|c|c|c|c|c|c|c|c|c|c|c|c|c|c|c|}
\hline Sequence & $\mathbf{G}$ & $\mathbf{E}$ & $\mathbf{W}$ & $\mathbf{T}$ & $\mathbf{Y}$ & $\mathbf{D}$ & $\mathbf{D}$ & $\mathbf{A}$ & $\mathbf{T}$ & $\mathbf{K}$ & $\mathbf{T}$ & $\mathbf{F}$ & $\mathbf{T}$ & $\mathbf{V}$ & $\mathbf{T}$ & $\mathbf{E}$ \\
\hline a a position & 1 & 2 & 3 & 4 & 5 & 6 & 7 & 8 & 9 & 10 & 11 & 12 & 13 & 14 & 15 & 16 \\
\hline$N_{0}{ }^{1}$ & 0 & 1 & 2 & 3 & 4 & 3 & 4 & 5 & 6 & 7 & 6 & 7 & 3 & 4 & 3 & 4 \\
\hline$N_{0}{ }^{\mathrm{r}}$ & 4 & 3 & 7 & 3 & 7 & 4 & 5 & 4 & 3 & 4 & 3 & 4 & 3 & 2 & 1 & 0 \\
\hline$a a N_{b l o b}$ & 5 & 5 & 10 & 7 & 12 & 8 & 10 & 10 & 10 & 12 & 10 & 12 & 7 & 7 & 5 & 5 \\
\hline blob 1 & & & & & $\mathbf{1 2}$ & & & & & & & & & & & \\
\hline Remainder & & & & & & & & & & & & & 7 & 7 & 5 & 5 \\
\hline blob 2 & & & & & & & & & & & & & & $\mathbf{7}$ & & \\
\hline
\end{tabular}

The first step used to calculate $<N_{\text {blob }}>$ and $n_{\mathrm{b}}$ was to determine the largest $N_{\text {blob }}$ value in the protein. The largest $N_{\text {blob }}$ value for the 1PGB fragment in Table S5 is 12, which was found for 
the $a a$ 's at position 5,10 , and 12 . Since there is more than one $a a$ with the same $N_{\text {blob value, there }}$ were multiple positions for the placement of the first blob. For each position, all aa's within $N_{0}{ }^{1}$ and $N_{0}{ }^{\mathrm{r}} a a$ 's from the chosen $a a$ were removed from the sequence. Assuming that tyrosine (Y) at position 5 was chosen, the $4 a a^{\text {'s }}$ to the left of tyrosine were removed from the sequence since $N_{0}{ }^{1}$ $=4$. Similarly, since the $N_{0}{ }^{\mathrm{r}}$ value of tyrosine was 7 , the $7 a a$ 's to the right were also removed. The $12(=7+3+1) a a$ 's removed from the sequence marked the first blob (blob 1 in Table S5, highlighted in green). This left behind the $a a$ 's at positions 13 to 16 . Of the remaining sequence,

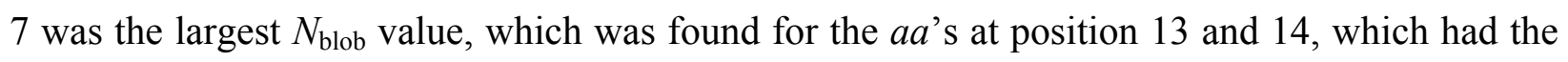
second largest $b l o b$ with $N_{\text {blob }}=7$. Since more than one $a a$ shared the same $N_{\text {blob }}$ value, there were two possible positions for the placement of the second blob. Assuming that valine (V) at position 14 was selected, the $a a^{\prime} s$ located $N_{0}^{1}$ and $N_{0}{ }^{\mathrm{r}} a a^{\prime}$ 's to, respectively, the left and right of valine were removed to yield blob 2 in Table S5, highlighted in blue, which consumed the remainder of the sequence. As a side note, the $N_{0}{ }^{1}$ value of valine extended past the remaining sequence by $3 a a$ 's (positions 10 - 12 in Table S5). Consequently, these 3 aa's were expected to be contained inside

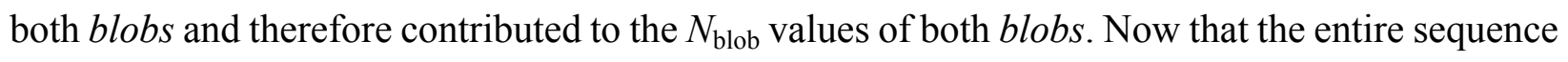
had been segmented into blobs, the number of blobs $n_{\mathrm{b}}$ was determined by tallying the blobs and

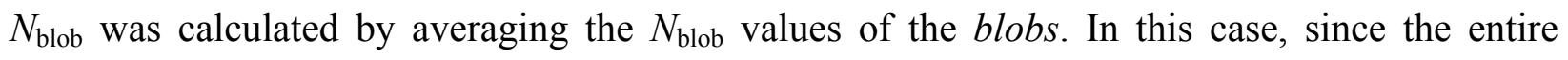
sequence was contained within two blobs $n_{\mathrm{b}}=2$, and $<N_{\mathrm{blob}}>=(12+7) / 2=9.5$.

The above procedure was repeated for every possible combination of blobs. The protein folding time $\left(\tau_{\mathrm{F}}\right)$ was calculated according to Equation 8 for each $<N_{\text {blob }}>$ and $n_{\mathrm{b}}$ combination that resulted from this systematic search. The average and standard deviation of these $\tau_{\mathrm{F}}$ values were calculated and they were included in the plot shown in Figure 9 in the main text. Since it would be difficult to provide the complete list of $\left\langle N_{\mathrm{blob}}>\right.$ and $n_{\mathrm{b}}$ combinations obtained for a single protein, 
the systematic search for the different combinations of $N_{\mathrm{blob}}$ and $n_{\mathrm{b}}$ values meant that these values could be averaged to obtain $\left\langle N_{\text {blob }}>\right.$ and $<n_{\mathrm{b}}>$ for a protein, which were then listed in Table S5. Taking the 1PGB fragment in Table S5 as an example, 7 possible combinations of blobs were obtained, which upon averaging led to $\left\langle N_{\text {blob }}>\right.$ and $\left\langle n_{\mathrm{b}}>\right.$ values of 8.47 and 2.57 , respectively. The seven possible combinations of blobs using the above method are: [5,13], [5,14], [1,10,15], $[1,10,16],[2,10,15],[2,10,16]$, and $[3,12]$, where the numbers contained in each bracket indicate the locations of each $b l o b$ for a given combination of $<N_{\mathrm{blob}}>$ and $n_{\mathrm{b}}$ values.

\section{J] Additional discussion on the blob size calculations:}

As discussed in the main text, $N_{0}$ was defined as the number of $a a$ 's separating a reference $a a$ from another $a a$ while still allowing the two $a a$ 's to interact with each other. As a result, a blob can contain $a a$ 's, that might not directly interact with the reference $a a$. An example of this effect would be a sequence containing a glutamic acid, alanine, and lysine at positions $i, i+5$, and $i+6$, respectively. If alanine has the smallest SCS in the sequence, $f_{\mathrm{b}}(\mathrm{SCS})$ equals 1.46 (Table S4). Since $[N($ glutamic acid $)+N($ alanine $)] \times f_{\mathrm{b}}(\mathrm{SCS})=(1.78+0.89) \times 1.46=3.90$ is less than 5, which is the number of $a a$ 's separating alanine from glutamic acid, alanine at position $i+5$ is predicted to not be able to interact with the glutamic acid at position $i$. However, $[N($ glutamic acid $)+$ $N($ lysine $)] \times f_{\mathrm{b}}(\mathrm{SCS})=(1.78+2.68) \times 1.46=6.51$ is greater than 6 , implying that lysine at position $i+6$ can interact with glutamic acid. This means that the $N_{0}$ value of glutamic acid will include alanine, although these two $a a$ 's are not predicted to directly interact with one another. Although some smaller $a a$ 's might not be able to touch the reference $a a$ inside a $b l o b$, these small $a a$ 's would still contribute to increasing the number of conformations taken by the oligopeptide segment constituting the blob and must thus be included in the calculations. 
To determine the average $b l o b$ size representative of a protein, the $a a^{\prime}$ 's included in $N_{0}{ }^{1}$ and $N_{0}{ }^{\mathrm{r}}$ of the $a a$ with the largest $N_{\text {blob }}$ value were considered to be contained within its $b l o b$. This had two implications. The first was that the $a a$ 's near a $b l o b$ 's periphery were expected to interact with other $a a$ 's outside the volume of the blob. Second, the blobs in a protein will often overlap with one another, meaning that some $a a^{\text {'s }}$ will be contained in more than one blob. This interpretation of the blobs suggests that a protein should not contain discrete segments of interacting $a a$ 's but rather that the $a a^{\prime}$ 's interact with one another in a continuum and that $\left\langle N_{b l o b}>\right.$ simply represents the ensemble average number of $a a$ 's capable of interacting with one another. Although the 'double counting' of some $a a^{\prime}$ 's shared by neighboring blobs towards $\left\langle N_{\text {blob }}>\right.$ might first appear to artificially increase the total number of conformation $\Omega$ of the protein, the $a a$ 's contained in more than one $b l o b$ do contribute to the $\Omega$ value of each $b l o b$, since these $a a$ 's must adopt their preferred conformation in all blobs involved, and as such must be counted toward the final $\Omega$.

Lastly, since the predicted folding times depended on experimental results, there are bound to be errors in the predicted values. To ensure that the predicted $\tau_{\mathrm{f}}$ 's would not change too much if the constraints defining the contacts between two $a a$ 's were relaxed, the calculation of folding times were repeated assuming that the $a a$ 's could still interact with one another, if the reach between them was extended by $\Delta l$ bond lengths as depicted in Figure S4. The number of $a a$ 's contained within $\Delta l$ bond lengths is equal to $N(\Delta l) \times f_{\mathrm{b}}$ (SCS), thereby extending the $N_{0}$ values by $N(\Delta l) \times f_{\mathrm{b}}(\mathrm{SCS})$. The new relationships defining the $N_{0}$ values are provided in Figure S4. A negative $\Delta l$ would illustrate a scenario where the $N(\mathrm{SCR})$ values overestimated the number of $a a$ 's, while a positive $\Delta l$ would represent either an underestimation of $N(\mathrm{SCR})$ or a situation where the side chains could interact with one another without directly touching each other, such as through hydrogen bonding with one another or with a nearby molecule (ex. water). 


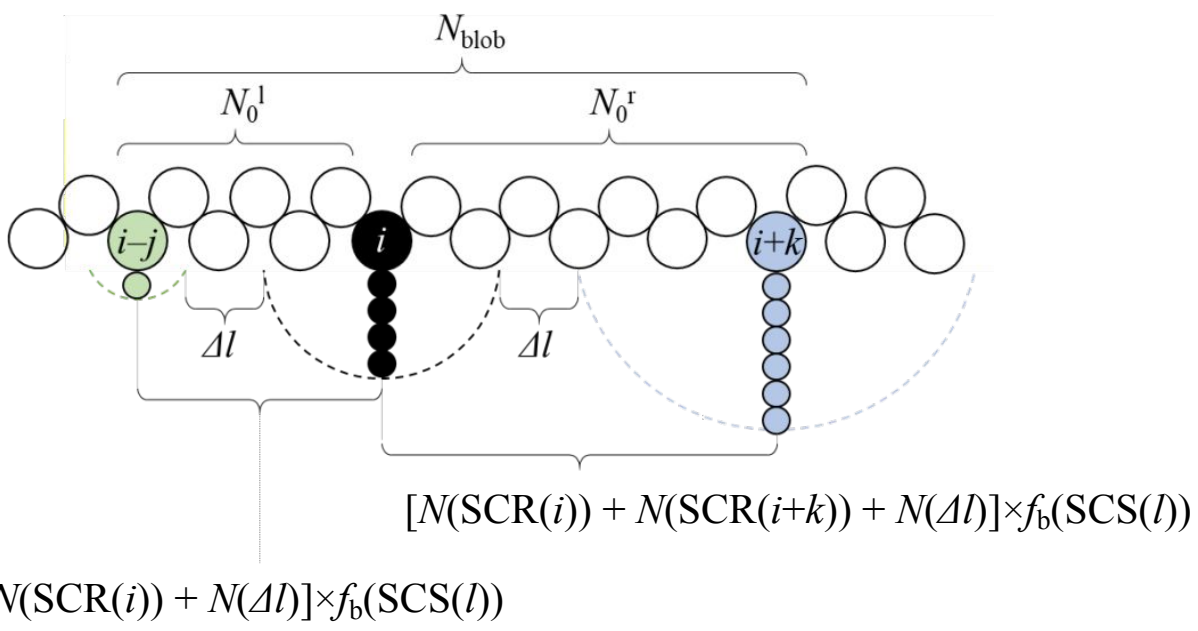

Figure S4. Schematic diagram of the $N_{\text {blob }}$ calculation assuming that $a a$ 's could interact with one another by a distance defined by their SCRs plus an additional $\Delta l$ bond lengths.

To assess how changes in $\Delta l$ affected the results, the correlation coefficient between the logarithms of the calculated and experimental folding times and their average difference was plotted as a function of $\Delta l$ in Figures S5A and B, respectively. Figure S5A shows that $r$ was similar ( $\sim 0.74)$ for all the $\Delta l$ values ranging from -1 to 3 , indicating that the correlation was little affected by this range of $\Delta l$ values. The average difference between the calculated and experimental folding times in Figure S5B shows that the lowest difference was obtained when $\Delta l=0$, and the further the deviation from 0 , the larger the difference between the folding times. However, there is almost no change in the predicted folding times for small deviations in $\Delta l$. Overall, small $\Delta l$ values had a minimal effect on the parameters in Figures S5A and B, demonstrating that the method used to determine the $\tau_{\mathrm{f}}$ 's is stable to perturbations in $b l o b$ sizes due to potential effects not included in the current program. 

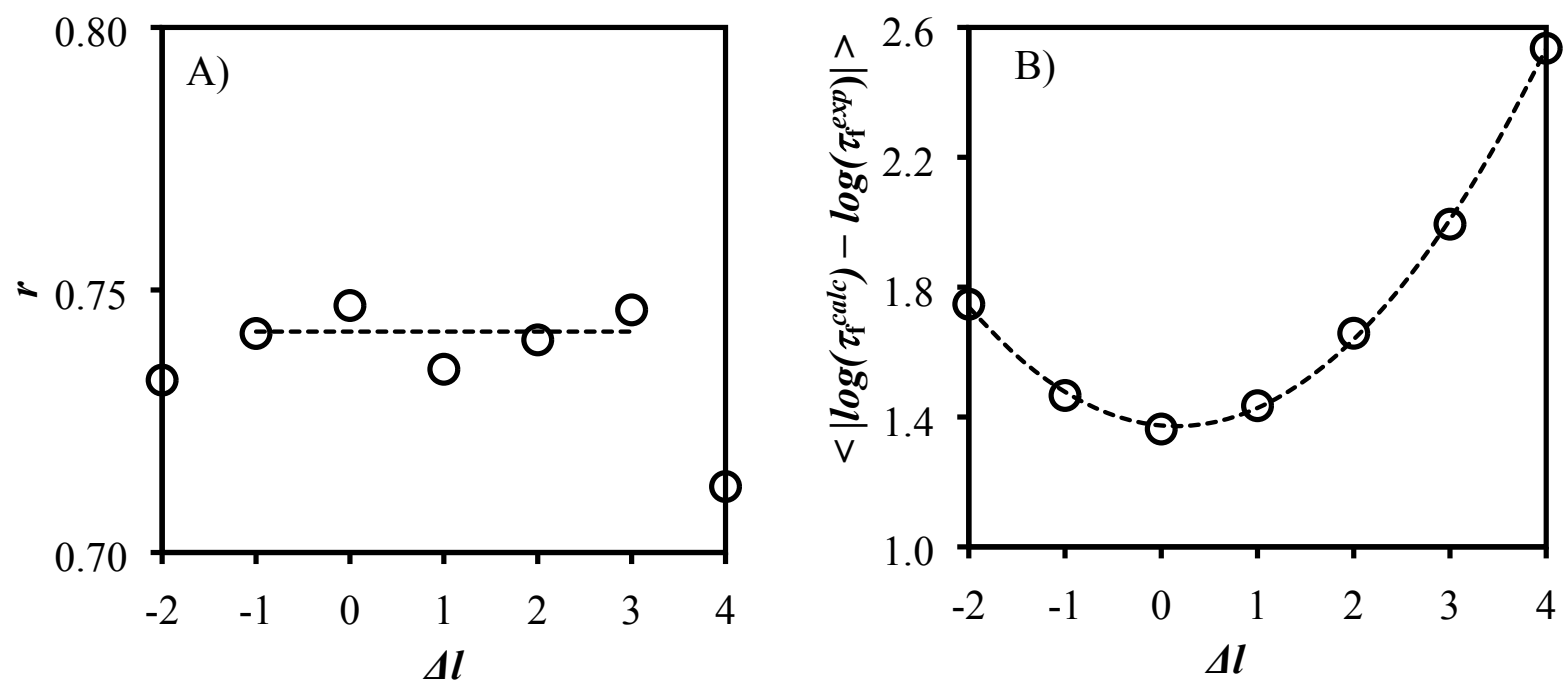

Figure S5. Plots of A) the correlation coefficient $(r)$ and $\mathrm{B}$ ) the average absolute difference between the logarithms of the $\tau_{\mathrm{f}}$ 's calculated using Equation 6 in the main text $\left(\tau_{\mathrm{f}}^{\text {calc }}\right)$ and the experimentally measured ones ( $\tau_{\mathrm{f}}^{\text {exp }}$ ) as the constraints of the $N_{0}$ values defining the $N_{\text {blob values }}$ changed by the length of a single atom $(\Delta l) . N_{0}{ }^{1}$ and $N_{0}{ }^{\mathrm{r}}$ were defined by the largest integer satisfying the conditions $j \leq[N(\operatorname{SCR}(i-j))+N(\operatorname{SCR}(j))+N(\Delta l)] \times f_{\mathrm{b}}(\operatorname{SCS}(i-j \rightarrow i))$ and $k \leq$ $[N(\operatorname{SCR}(i))+N(\operatorname{SCR}(i+k))+N(\Delta l)] \times f_{\mathrm{b}}(\operatorname{SCS}(i \rightarrow i+k))$, respectively. 


\section{K] Proteins and their folding times:}

Table S6. List of peptides and proteins with their degree of polymerization (DP), logarithm of experimental folding times ${ }^{3,4}$, average logarithm of calculated folding times, average blob size $<N_{\text {blob }}>$, and average number of blobs $\left\langle n_{\mathrm{b}}>\right.$. The identity lists the code from the protein data bank (PDB) and if only part of the sequence was used for the folding experiment, it is indicated in the parentheses.

\begin{tabular}{|c|c|c|c|c|c|c|}
\hline Identity & DP & $\begin{array}{c}\text { Experimental } \\
\log \left(\tau_{\mathrm{F}}\right)\end{array}$ & $\begin{array}{l}\text { Calculated } \\
\log \left(<\tau_{\mathrm{F}}>\right)\end{array}$ & $<N_{b l o b}>$ & $<n_{\mathrm{b}}>$ & $\begin{array}{c}\text { \# of blob } \\
\text { strings }\end{array}$ \\
\hline $\begin{array}{c}\text { 1PGB } \\
(41-56)\end{array}$ & 16 & -5.43 & $\begin{array}{c}-7.82 \\
( \pm 1.60)\end{array}$ & $\begin{array}{c}8.48 \\
( \pm 1.51)\end{array}$ & $\begin{array}{c}2.57 \\
( \pm 0.53)\end{array}$ & 7 \\
\hline $1 \mathrm{~L} 2 \mathrm{Y}$ & 20 & -5.40 & $\begin{array}{c}-6.65 \\
( \pm 0.00)\end{array}$ & $\begin{array}{c}12.00 \\
( \pm 0.00)\end{array}$ & $\begin{array}{c}2.00 \\
( \pm 0.00)\end{array}$ & 2 \\
\hline Alpha Helix & 21 & -6.73 & $\begin{array}{c}-8.15 \\
( \pm 0.62)\end{array}$ & $\begin{array}{c}4.76 \\
( \pm 0.19)\end{array}$ & $\begin{array}{c}6.03 \\
( \pm 0.62)\end{array}$ & 5124 \\
\hline $1 \mathrm{~T} 8 \mathrm{~J}$ & 25 & -5.12 & $\begin{array}{c}-6.63 \\
( \pm 0.13)\end{array}$ & $\begin{array}{c}10.95 \\
( \pm 0.13)\end{array}$ & $\begin{array}{c}3.00 \\
( \pm 0.00)\end{array}$ & 7 \\
\hline $\begin{array}{c}\text { 1PIN } \\
(6-39)\end{array}$ & 34 & -4.08 & $\begin{array}{c}-3.85 \\
( \pm 0.00)\end{array}$ & $\begin{array}{c}17.50 \\
( \pm 0.00)\end{array}$ & $\begin{array}{c}2.00 \\
( \pm 0.00)\end{array}$ & 1 \\
\hline $\begin{array}{c}1 \text { VII } \\
(42-76)\end{array}$ & 35 & -5.34 & $\begin{array}{c}-2.84 \\
( \pm 0.00)\end{array}$ & $\begin{array}{c}19.50 \\
( \pm 0.00)\end{array}$ & $\begin{array}{c}2.00 \\
( \pm 0.00)\end{array}$ & 1 \\
\hline $1 \mathrm{E} 0 \mathrm{~L}$ & 37 & -4.39 & $\begin{array}{c}-3.38 \\
( \pm 0.00)\end{array}$ & $\begin{array}{c}17.33 \\
( \pm 0.00)\end{array}$ & $\begin{array}{c}3.00 \\
( \pm 0.00)\end{array}$ & 1 \\
\hline $1 \mathrm{E} 0 \mathrm{M}$ & 37 & -3.87 & $\begin{array}{c}-5.05 \\
( \pm 0.00)\end{array}$ & $\begin{array}{c}13.00 \\
( \pm 0.00)\end{array}$ & $\begin{array}{c}4.00 \\
( \pm 0.00)\end{array}$ & 1 \\
\hline $1 \mathrm{~K} 9 \mathrm{Q}$ & 40 & -3.65 & $\begin{array}{c}-3.89 \\
( \pm 0.00)\end{array}$ & $\begin{array}{c}16.33 \\
( \pm 0.00)\end{array}$ & $\begin{array}{c}3.00 \\
( \pm 0.00)\end{array}$ & 1 \\
\hline $1 \mathrm{~W} 4 \mathrm{E}$ & 45 & -4.43 & $\begin{array}{c}-3.77 \\
( \pm 0.42)\end{array}$ & $\begin{array}{c}14.97 \\
( \pm 1.10)\end{array}$ & $\begin{array}{c}4.50 \\
( \pm 0.71)\end{array}$ & 2 \\
\hline $\begin{array}{l}\text { 1PRB } \\
(7-53)\end{array}$ & 47 & -5.99 & $\begin{array}{c}-5.12 \\
( \pm 0.00)\end{array}$ & $\begin{array}{c}10.83 \\
( \pm 0.00)\end{array}$ & $\begin{array}{c}6.00 \\
( \pm 0.00)\end{array}$ & 6 \\
\hline $2 \mathrm{WXC}$ & 47 & -5.08 & $\begin{array}{c}-4.93 \\
( \pm 0.00)\end{array}$ & $\begin{array}{c}13.25 \\
( \pm 0.00)\end{array}$ & $\begin{array}{c}4.00 \\
( \pm 0.00)\end{array}$ & 2 \\
\hline $1 \mathrm{E} 0 \mathrm{G}$ & 48 & -3.04 & $\begin{array}{c}-2.41 \\
( \pm 0.18)\end{array}$ & $\begin{array}{c}18.89 \\
( \pm 0.77)\end{array}$ & $\begin{array}{c}3.33 \\
( \pm 0.58)\end{array}$ & 3 \\
\hline $1 \mathrm{OKS}$ & 49 & -2.69 & $\begin{array}{c}-4.63 \\
( \pm 0.40)\end{array}$ & $\begin{array}{c}11.42 \\
( \pm 0.39)\end{array}$ & $\begin{array}{c}6.28 \\
( \pm 0.67)\end{array}$ & 18 \\
\hline $1 \mathrm{~W} 4 \mathrm{~J}$ & 51 & -5.34 & $\begin{array}{c}-4.35 \\
( \pm 0.00)\end{array}$ & $\begin{array}{c}12.33 \\
( \pm 0.00)\end{array}$ & $\begin{array}{c}6.00 \\
( \pm 0.00)\end{array}$ & 1 \\
\hline $2 \mathrm{WQG}$ & 51 & -3.69 & $\begin{array}{c}-4.67 \\
( \pm 0.00)\end{array}$ & $\begin{array}{c}13.75 \\
( \pm 0.00)\end{array}$ & $\begin{array}{c}4.00 \\
( \pm 0.00)\end{array}$ & 1 \\
\hline
\end{tabular}




\begin{tabular}{|c|c|c|c|c|c|c|}
\hline $\begin{array}{c}2 \mathrm{LLH} \\
(19-70)\end{array}$ & 52 & -3.04 & $\begin{array}{c}-4.01 \\
( \pm 0.36)\end{array}$ & $\begin{array}{c}14.59 \\
( \pm 0.90)\end{array}$ & $\begin{array}{c}4.40 \\
( \pm 0.55)\end{array}$ & 5 \\
\hline 1BA5 & 53 & -2.56 & $\begin{array}{c}-3.51 \\
( \pm 0.00)\end{array}$ & $\begin{array}{c}15.00 \\
( \pm 0.00)\end{array}$ & $\begin{array}{c}5.00 \\
( \pm 0.00)\end{array}$ & 2 \\
\hline 1IDY & 54 & -3.78 & $\begin{array}{c}-4.24 \\
( \pm 0.46)\end{array}$ & $\begin{array}{c}13.47 \\
( \pm 0.52)\end{array}$ & $\begin{array}{c}5.00 \\
( \pm 0.00)\end{array}$ & 6 \\
\hline $1 \mathrm{ENH}$ & 54 & -4.60 & $\begin{array}{c}-4.08 \\
( \pm 0.46)\end{array}$ & $\begin{array}{c}12.96 \\
( \pm 0.74)\end{array}$ & $\begin{array}{c}5.83 \\
( \pm 0.72)\end{array}$ & 12 \\
\hline $\begin{array}{c}1 \text { DIV } \\
(1-56)\end{array}$ & 56 & -2.84 & $\begin{array}{c}-3.50 \\
( \pm 0.00)\end{array}$ & $\begin{array}{c}14.00 \\
( \pm 0.00)\end{array}$ & $\begin{array}{c}6.00 \\
( \pm 0.00)\end{array}$ & 1 \\
\hline $\begin{array}{l}1 \mathrm{SRL} \\
(9-64)\end{array}$ & 56 & -1.91 & $\begin{array}{c}-3.50 \\
( \pm 0.47)\end{array}$ & $\begin{array}{c}15.64 \\
( \pm 1.13)\end{array}$ & $\begin{array}{c}4.25 \\
( \pm 0.46)\end{array}$ & 8 \\
\hline 1PGB & 56 & -2.78 & $\begin{array}{c}-3.65 \\
( \pm 0.40)\end{array}$ & $\begin{array}{c}13.78 \\
( \pm 0.55)\end{array}$ & $\begin{array}{c}5.86 \\
( \pm 0.36)\end{array}$ & 14 \\
\hline $\begin{array}{c}\text { 1AVZ } \\
\text { (Chain C: } 85-141)\end{array}$ & 57 & -2.13 & $\begin{array}{c}-3.06 \\
( \pm 1.54)\end{array}$ & $\begin{array}{c}15.53 \\
( \pm 1.15)\end{array}$ & $\begin{array}{c}4.88 \\
( \pm 0.35)\end{array}$ & 8 \\
\hline $\begin{array}{l}1 \mathrm{SHG} \\
(6-62)\end{array}$ & 57 & -0.48 & $\begin{array}{c}-3.19 \\
( \pm 0.20)\end{array}$ & $\begin{array}{c}14.93 \\
( \pm 0.75)\end{array}$ & $\begin{array}{c}5.67 \\
( \pm 0.58)\end{array}$ & 3 \\
\hline $1 \mathrm{JO} 8$ & 58 & -1.09 & $\begin{array}{c}-3.92 \\
( \pm 0.30)\end{array}$ & $\begin{array}{c}12.14 \\
( \pm 0.26)\end{array}$ & $\begin{array}{c}7.00 \\
( \pm 0.00)\end{array}$ & 4 \\
\hline $\begin{array}{c}1 \mathrm{AU} 7 \\
(103-160)\end{array}$ & 58 & -4.21 & $\begin{array}{c}-4.10 \\
( \pm 0.00)\end{array}$ & $\begin{array}{c}12.83 \\
( \pm 0.00)\end{array}$ & $\begin{array}{c}6.00 \\
( \pm 0.00)\end{array}$ & 3 \\
\hline $1 \mathrm{FEX}$ & 59 & -3.56 & $\begin{array}{c}-4.29 \\
( \pm 0.09)\end{array}$ & $\begin{array}{c}12.44 \\
( \pm 0.08)\end{array}$ & $\begin{array}{c}6.00 \\
( \pm 0.00)\end{array}$ & 12 \\
\hline $\begin{array}{c}1 \mathrm{SS} 1 \\
(2-60)\end{array}$ & 59 & -4.99 & $\begin{array}{c}-4.06 \\
( \pm 0.27)\end{array}$ & $\begin{array}{c}11.52 \\
( \pm 0.50)\end{array}$ & $\begin{array}{c}7.33 \\
( \pm 0.58)\end{array}$ & 3 \\
\hline $\begin{array}{c}\text { 2PTL } \\
(18-77)\end{array}$ & 62 & -1.78 & $\begin{array}{c}-3.84 \\
( \pm 0.00)\end{array}$ & $\begin{array}{c}13.33 \\
( \pm 0.00)\end{array}$ & $\begin{array}{c}6.00 \\
( \pm 0.00)\end{array}$ & 1 \\
\hline 2L6R & 62 & -4.47 & $\begin{array}{c}-3.10 \\
( \pm 0.00)\end{array}$ & $\begin{array}{c}15.80 \\
( \pm 0.00)\end{array}$ & $\begin{array}{c}5.00 \\
( \pm 0.00)\end{array}$ & 6 \\
\hline $3 \mathrm{CI} 2$ & 64 & -2.52 & $\begin{array}{c}-3.57 \\
( \pm 0.00)\end{array}$ & $\begin{array}{c}12.86 \\
( \pm 0.00)\end{array}$ & $\begin{array}{c}7.00 \\
( \pm 0.00)\end{array}$ & 9 \\
\hline $1 \mathrm{C} 8 \mathrm{C}$ & 64 & -3.04 & $\begin{array}{c}-2.25 \\
( \pm 0.25)\end{array}$ & $\begin{array}{c}17.47 \\
( \pm 0.23)\end{array}$ & $\begin{array}{c}5.00 \\
( \pm 0.00)\end{array}$ & 3 \\
\hline $\begin{array}{l}2 \mathrm{CRO} \\
(1-65)\end{array}$ & 65 & -1.61 & $\begin{array}{c}-3.09 \\
( \pm 0.16)\end{array}$ & $\begin{array}{c}13.79 \\
( \pm 0.13)\end{array}$ & $\begin{array}{c}7.00 \\
( \pm 0.00)\end{array}$ & 12 \\
\hline $1 \mathrm{C} 9 \mathrm{O}$ & 66 & -3.13 & $\begin{array}{c}-1.50 \\
( \pm 0.00)\end{array}$ & $\begin{array}{c}20.00 \\
( \pm 0.00)\end{array}$ & $\begin{array}{c}4.00 \\
( \pm 0.00)\end{array}$ & 1 \\
\hline 1G6P & 66 & -2.74 & $\begin{array}{c}-1.85 \\
( \pm 0.74)\end{array}$ & $\begin{array}{c}17.56 \\
( \pm 0.74)\end{array}$ & $\begin{array}{c}5.40 \\
( \pm 0.55)\end{array}$ & 5 \\
\hline $\begin{array}{l}2 \mathrm{VKN} \\
(1-66)\end{array}$ & 66 & -0.91 & $\begin{array}{c}-3.01 \\
( \pm 0.55)\end{array}$ & $\begin{array}{c}15.09 \\
( \pm 0.80)\end{array}$ & $\begin{array}{c}5.80 \\
( \pm 0.42)\end{array}$ & 10 \\
\hline $1 \mathrm{CSP}$ & 67 & -2.82 & $\begin{array}{c}-2.49 \\
( \pm 0.00)\end{array}$ & $\begin{array}{c}17.00 \\
( \pm 0.00)\end{array}$ & $\begin{array}{c}5.00 \\
( \pm 0.00)\end{array}$ & 1 \\
\hline 1RYK & 69 & -3.95 & $\begin{array}{c}-2.21 \\
( \pm 0.60)\end{array}$ & $\begin{array}{c}16.78 \\
( \pm 1.07)\end{array}$ & $\begin{array}{c}5.67 \\
( \pm 0.58)\end{array}$ & 3 \\
\hline
\end{tabular}




\begin{tabular}{|c|c|c|c|c|c|c|}
\hline $1 \mathrm{MJC}$ & 69 & -2.30 & $\begin{array}{c}-2.52 \\
( \pm 0.90)\end{array}$ & $\begin{array}{c}16.67 \\
( \pm 0.72)\end{array}$ & $\begin{array}{c}5.00 \\
( \pm 0.00)\end{array}$ & 6 \\
\hline $\begin{array}{c}1 \mathrm{UZC} \\
(3-71)\end{array}$ & 69 & -3.47 & $\begin{array}{c}-3.27 \\
( \pm 0.19)\end{array}$ & $\begin{array}{c}13.43 \\
( \pm 0.16)\end{array}$ & $\begin{array}{c}7.00 \\
( \pm 0.00)\end{array}$ & 4 \\
\hline $\begin{array}{l}\text { 1DKT } \\
(5-76)\end{array}$ & 72 & -1.95 & $\begin{array}{c}-3.21 \\
( \pm 0.42)\end{array}$ & $\begin{array}{c}11.97 \\
( \pm 0.24)\end{array}$ & $\begin{array}{c}8.50 \\
( \pm 0.51)\end{array}$ & 34 \\
\hline $2 \mathrm{~A} 3 \mathrm{D}$ & 73 & -5.30 & $\begin{array}{c}-2.99 \\
( \pm 0.00)\end{array}$ & $\begin{array}{c}15.00 \\
( \pm 0.00)\end{array}$ & $\begin{array}{c}6.00 \\
( \pm 0.00)\end{array}$ & 2 \\
\hline $\begin{array}{c}1 \text { RFA } \\
(56-130)\end{array}$ & 75 & -3.34 & $\begin{array}{c}-1.97 \\
( \pm 0.00)\end{array}$ & $\begin{array}{c}17.00 \\
( \pm 0.00) \\
\end{array}$ & $\begin{array}{c}6.00 \\
( \pm 0.00)\end{array}$ & 12 \\
\hline 2JMC & 75 & -1.43 & $\begin{array}{c}-2.52 \\
( \pm 0.44)\end{array}$ & $\begin{array}{c}16.42 \\
( \pm 0.98)\end{array}$ & $\begin{array}{c}5.40 \\
( \pm 0.50)\end{array}$ & 40 \\
\hline $\begin{array}{c}1 \mathrm{M} 9 \mathrm{~S} \\
(391-466)\end{array}$ & 76 & -1.74 & $\begin{array}{c}-1.07 \\
( \pm 0.00)\end{array}$ & $\begin{array}{c}19.80 \\
( \pm 0.00)\end{array}$ & $\begin{array}{c}5.00 \\
( \pm 0.00)\end{array}$ & 2 \\
\hline $1 \mathrm{UBQ}$ & 76 & -2.30 & $\begin{array}{c}-3.00 \\
( \pm 0.08)\end{array}$ & $\begin{array}{c}13.21 \\
( \pm 0.40)\end{array}$ & $\begin{array}{c}7.75 \\
( \pm 0.46)\end{array}$ & 8 \\
\hline $\begin{array}{l}\text { 1LMB } \\
(6-85)\end{array}$ & 80 & -4.52 & $\begin{array}{c}-3.03 \\
( \pm 0.45)\end{array}$ & $\begin{array}{c}13.84 \\
( \pm 0.35)\end{array}$ & $\begin{array}{c}7.00 \\
( \pm 0.00)\end{array}$ & 54 \\
\hline $\begin{array}{c}1 \mathrm{KDX} \\
(586-666)\end{array}$ & 80 & -3.39 & $\begin{array}{c}-2.88 \\
( \pm 0.42)\end{array}$ & $\begin{array}{c}13.22 \\
( \pm 0.28)\end{array}$ & $\begin{array}{c}7.89 \\
( \pm 0.31)\end{array}$ & 38 \\
\hline $106 X$ & 81 & -2.95 & $\begin{array}{c}-2.87 \\
( \pm 0.23)\end{array}$ & $\begin{array}{c}12.79 \\
( \pm 0.53)\end{array}$ & $\begin{array}{c}8.40 \\
( \pm 0.50)\end{array}$ & 20 \\
\hline $\begin{array}{c}1 \mathrm{EHB} \\
(3-84)\end{array}$ & 82 & -1.30 & $\begin{array}{c}-2.18 \\
( \pm 0.00)\end{array}$ & $\begin{array}{c}15.57 \\
( \pm 0.00)\end{array}$ & $\begin{array}{c}7.00 \\
( \pm 0.00)\end{array}$ & 6 \\
\hline $\begin{array}{c}1 \mathrm{PNJ} \\
(3-84)\end{array}$ & 82 & 0.30 & $\begin{array}{c}-1.55 \\
( \pm 0.00)\end{array}$ & $\begin{array}{c}17.83 \\
( \pm 0.00)\end{array}$ & $\begin{array}{c}6.00 \\
( \pm 0.00)\end{array}$ & 8 \\
\hline $\begin{array}{c}1 \text { PRS } \\
(91-173)\end{array}$ & 83 & 0.87 & $\begin{array}{c}-2.47 \\
( \pm 0.00)\end{array}$ & $\begin{array}{c}15.00 \\
( \pm 0.00)\end{array}$ & $\begin{array}{c}7.00 \\
( \pm 0.00)\end{array}$ & 4 \\
\hline $1 \mathrm{HDN}$ & 85 & -1.17 & $\begin{array}{c}-2.45 \\
( \pm 0.12)\end{array}$ & $\begin{array}{c}14.54 \\
( \pm 0.62)\end{array}$ & $\begin{array}{c}7.50 \\
( \pm 0.52)\end{array}$ & 16 \\
\hline $\begin{array}{l}2 \mathrm{BKF} \\
(1-85)\end{array}$ & 85 & -2.69 & $\begin{array}{c}-2.77 \\
( \pm 0.29)\end{array}$ & $\begin{array}{c}12.20 \\
( \pm 0.20)\end{array}$ & $\begin{array}{c}9.18 \\
( \pm 0.39)\end{array}$ & 264 \\
\hline 1IMQ & 86 & -3.18 & $\begin{array}{c}-2.35 \\
( \pm 0.25)\end{array}$ & $\begin{array}{c}12.70 \\
( \pm 0.32)\end{array}$ & $\begin{array}{c}9.50 \\
( \pm 0.53)\end{array}$ & 8 \\
\hline 1ST7 & 86 & -3.69 & $\begin{array}{c}-2.41 \\
( \pm 0.00)\end{array}$ & $\begin{array}{c}13.79 \\
( \pm 0.49)\end{array}$ & $\begin{array}{c}8.33 \\
( \pm 0.48)\end{array}$ & 24 \\
\hline $\begin{array}{c}\text { 1AYI } \\
(1-86)\end{array}$ & 86 & -2.48 & $\begin{array}{c}-2.55 \\
( \pm 0.27)\end{array}$ & $\begin{array}{c}12.19 \\
( \pm 0.24)\end{array}$ & $\begin{array}{c}9.62 \\
( \pm 0.49)\end{array}$ & 52 \\
\hline 1NTI & 86 & -2.82 & $\begin{array}{c}-2.42 \\
( \pm 0.65)\end{array}$ & $\begin{array}{c}13.47 \\
( \pm 0.44)\end{array}$ & $\begin{array}{c}8.44 \\
( \pm 0.50)\end{array}$ & 90 \\
\hline $\begin{array}{l}1 \mathrm{~K} 8 \mathrm{M} \\
(1-87)\end{array}$ & 87 & 0.41 & $\begin{array}{c}-2.26 \\
( \pm 0.00)\end{array}$ & $\begin{array}{c}15.43 \\
( \pm 0.00)\end{array}$ & $\begin{array}{c}7.00 \\
( \pm 0.00)\end{array}$ & 32 \\
\hline $\begin{array}{c}1 \mathrm{PRS} \\
(1-88)\end{array}$ & 88 & -1.30 & $\begin{array}{c}-1.90 \\
( \pm 0.00)\end{array}$ & $\begin{array}{c}14.62 \\
( \pm 0.54)\end{array}$ & $\begin{array}{c}8.50 \\
( \pm 0.53)\end{array}$ & 8 \\
\hline $1 \mathrm{~K} 85$ & 88 & -0.61 & $\begin{array}{c}-2.68 \\
( \pm 0.37)\end{array}$ & $\begin{array}{c}11.27 \\
( \pm 0.40)\end{array}$ & $\begin{array}{c}10.25 \\
( \pm 0.66)\end{array}$ & 288 \\
\hline
\end{tabular}




\begin{tabular}{|c|c|c|c|c|c|c|}
\hline $\begin{array}{c}1 \mathrm{GXT} \\
(4-91)\end{array}$ & 88 & -1.91 & $\begin{array}{c}-2.62 \\
( \pm 0.00)\end{array}$ & $\begin{array}{c}14.71 \\
( \pm 0.00)\end{array}$ & $\begin{array}{c}7.00 \\
( \pm 0.00)\end{array}$ & 2 \\
\hline $\begin{array}{c}\text { 1TEN } \\
(803-891)\end{array}$ & 89 & -0.78 & $\begin{array}{c}-1.81 \\
( \pm 0.21)\end{array}$ & $\begin{array}{c}14.78 \\
( \pm 0.67)\end{array}$ & $\begin{array}{c}8.50 \\
( \pm 0.52)\end{array}$ & 12 \\
\hline 1BTA & 89 & -1.52 & $\begin{array}{c}-2.11 \\
( \pm 0.00)\end{array}$ & $\begin{array}{c}15.71 \\
( \pm 0.00)\end{array}$ & $\begin{array}{c}7.00 \\
( \pm 0.00)\end{array}$ & 8 \\
\hline $1 \mathrm{TIT}$ & 89 & -1.56 & $\begin{array}{c}-2.21 \\
( \pm 0.36)\end{array}$ & $\begin{array}{c}13.33 \\
( \pm 0.18)\end{array}$ & $\begin{array}{c}9.13 \\
( \pm 0.35)\end{array}$ & 30 \\
\hline $\begin{array}{c}\text { 2BJD } \\
(12-101)\end{array}$ & 90 & -0.74 & $\begin{array}{c}-0.97 \\
( \pm 0.55)\end{array}$ & $\begin{array}{c}17.86 \\
( \pm 0.43)\end{array}$ & $\begin{array}{c}7.00 \\
( \pm 0.00)\end{array}$ & 9 \\
\hline $\begin{array}{c}1 \mathrm{FNF} \\
(1325-1415)\end{array}$ & 91 & 0.39 & $\begin{array}{c}-1.71 \\
( \pm 0.00)\end{array}$ & $\begin{array}{c}15.50 \\
( \pm 0.00)\end{array}$ & $\begin{array}{c}8.00 \\
( \pm 0.00)\end{array}$ & 2 \\
\hline $\begin{array}{l}\text { 3ZRT } \\
(3-93)\end{array}$ & 91 & -0.56 & $\begin{array}{c}-2.14 \\
( \pm 0.19)\end{array}$ & $\begin{array}{c}12.80 \\
( \pm 0.21)\end{array}$ & $\begin{array}{c}9.80 \\
( \pm 0.41)\end{array}$ & 20 \\
\hline $\begin{array}{c}1 \text { DIV } \\
(58-149)\end{array}$ & 92 & -1.43 & $\begin{array}{c}-2.35 \\
( \pm 0.00)\end{array}$ & $\begin{array}{c}13.22 \\
( \pm 0.00)\end{array}$ & $\begin{array}{c}9.00 \\
( \pm 0.00)\end{array}$ & 6 \\
\hline $\begin{array}{c}1 \mathrm{TP} 3 \\
(309-401)\end{array}$ & 93 & -1.30 & $\begin{array}{c}-1.39 \\
( \pm 0.00)\end{array}$ & $\begin{array}{c}16.12 \\
( \pm 0.00)\end{array}$ & $\begin{array}{c}8.00 \\
( \pm 0.00)\end{array}$ & 1 \\
\hline $1 \mathrm{WIT}$ & 93 & -0.18 & $\begin{array}{c}-1.77 \\
( \pm 0.00)\end{array}$ & $\begin{array}{c}15.38 \\
( \pm 0.00)\end{array}$ & $\begin{array}{c}8.00 \\
( \pm 0.00)\end{array}$ & 1 \\
\hline $\begin{array}{c}3 Z R T \\
(97-189)\end{array}$ & 93 & -0.13 & $\begin{array}{c}-1.59 \\
( \pm 0.11)\end{array}$ & $\begin{array}{c}14.91 \\
( \pm 0.48)\end{array}$ & $\begin{array}{c}8.80 \\
( \pm 0.40)\end{array}$ & 50 \\
\hline $\begin{array}{l}2 \mathrm{VH} 7 \\
(5-98)\end{array}$ & 94 & -0.36 & $\begin{array}{c}-1.26 \\
( \pm 0.00)\end{array}$ & $\begin{array}{c}16.38 \\
( \pm 0.00)\end{array}$ & $\begin{array}{c}8.00 \\
( \pm 0.00)\end{array}$ & 2 \\
\hline $\begin{array}{c}\text { 1GM1 } \\
(9-102)\end{array}$ & 94 & -0.43 & $\begin{array}{c}-1.02 \\
( \pm 0.00)\end{array}$ & $\begin{array}{c}17.86 \\
( \pm 0.00)\end{array}$ & $\begin{array}{c}7.00 \\
( \pm 0.00)\end{array}$ & 1 \\
\hline $\begin{array}{c}\text { 1AUE } \\
\text { (Chain B: 2022-2115) }\end{array}$ & 94 & -2.35 & $\begin{array}{c}-1.02 \\
( \pm 0.00)\end{array}$ & $\begin{array}{c}17.86 \\
( \pm 0.00)\end{array}$ & $\begin{array}{c}7.00 \\
( \pm 0.00)\end{array}$ & 4 \\
\hline $1 \mathrm{TTG}$ & 94 & -2.39 & $\begin{array}{c}-2.21 \\
( \pm 0.00)\end{array}$ & $\begin{array}{c}14.50 \\
( \pm 0.00)\end{array}$ & $\begin{array}{c}8.00 \\
( \pm 0.00)\end{array}$ & 24 \\
\hline $\begin{array}{l}1 \mathrm{FHT} \\
(2-97)\end{array}$ & 96 & -2.00 & $\begin{array}{c}-1.57 \\
( \pm 0.37)\end{array}$ & $\begin{array}{c}14.37 \\
( \pm 0.35)\end{array}$ & $\begin{array}{c}9.33 \\
( \pm 0.48)\end{array}$ & 24 \\
\hline $1 \mathrm{~N} 88$ & 96 & -0.87 & $\begin{array}{c}-1.34 \\
( \pm 0.51)\end{array}$ & $\begin{array}{c}15.23 \\
( \pm 0.34)\end{array}$ & $\begin{array}{c}8.86 \\
( \pm 0.36)\end{array}$ & 21 \\
\hline 1FA3 & 96 & -1.78 & $\begin{array}{c}-1.09 \\
( \pm 0.14)\end{array}$ & $\begin{array}{c}17.12 \\
( \pm 0.64)\end{array}$ & $\begin{array}{c}7.60 \\
( \pm 0.52)\end{array}$ & 10 \\
\hline $\begin{array}{c}\text { 1RIS } \\
(1-97)\end{array}$ & 97 & -2.65 & $\begin{array}{c}-1.90 \\
( \pm 0.00)\end{array}$ & $\begin{array}{c}14.11 \\
( \pm 0.00)\end{array}$ & $\begin{array}{c}9.00 \\
( \pm 0.00)\end{array}$ & 1 \\
\hline $\begin{array}{c}2 X 7 Z \\
(311-407)\end{array}$ & 97 & -0.32 & $\begin{array}{c}-1.65 \\
( \pm 0.24)\end{array}$ & $\begin{array}{c}14.78 \\
( \pm 0.62)\end{array}$ & $\begin{array}{c}8.80 \\
( \pm 0.45)\end{array}$ & 5 \\
\hline $\begin{array}{l}1 \mathrm{HNG} \\
(2-98)\end{array}$ & 97 & -0.78 & $\begin{array}{c}-1.69 \\
( \pm 0.19)\end{array}$ & $\begin{array}{c}15.02 \\
( \pm 0.39)\end{array}$ & $\begin{array}{c}8.50 \\
( \pm 0.55)\end{array}$ & 6 \\
\hline 1APS & 98 & 0.69 & $\begin{array}{c}-0.37 \\
( \pm 0.00)\end{array}$ & $\begin{array}{c}18.12 \\
( \pm 0.00)\end{array}$ & $\begin{array}{c}8.00 \\
( \pm 0.00)\end{array}$ & 2 \\
\hline 2QJL & 99 & -1.13 & $\begin{array}{c}-2.13 \\
( \pm 0.00)\end{array}$ & $\begin{array}{c}13.67 \\
( \pm 0.00)\end{array}$ & $\begin{array}{c}9.00 \\
( \pm 0.00)\end{array}$ & 8 \\
\hline
\end{tabular}




\begin{tabular}{|c|c|c|c|c|c|c|}
\hline $\begin{array}{c}1 \mathrm{E} 41 \\
(93-192)\end{array}$ & 100 & -3.00 & $\begin{array}{c}-1.97 \\
( \pm 0.24)\end{array}$ & $\begin{array}{c}12.93 \\
( \pm 0.21)\end{array}$ & $\begin{array}{c}10.00 \\
( \pm 0.00)\end{array}$ & 48 \\
\hline $\begin{array}{l}\text { 1PUC } \\
(2-102)\end{array}$ & 101 & -1.82 & $\begin{array}{c}-1.73 \\
( \pm 0.35)\end{array}$ & $\begin{array}{c}14.15 \\
( \pm 0.37)\end{array}$ & $\begin{array}{c}9.25 \\
( \pm 0.46)\end{array}$ & 8 \\
\hline $\begin{array}{c}1 \mathrm{SPR} \\
(2-104)\end{array}$ & 103 & -3.78 & $\begin{array}{c}-0.72 \\
( \pm 0.21)\end{array}$ & $\begin{array}{c}16.66 \\
( \pm 0.60)\end{array}$ & $\begin{array}{c}8.75 \\
( \pm 0.44)\end{array}$ & 32 \\
\hline $\begin{array}{c}\text { 1ARR } \\
(1-106)\end{array}$ & 106 & -4.00 & $\begin{array}{c}-0.81 \\
( \pm 0.13)\end{array}$ & $\begin{array}{c}16.23 \\
( \pm 0.12)\end{array}$ & $\begin{array}{c}9.00 \\
( \pm 0.00)\end{array}$ & 9 \\
\hline $\begin{array}{c}\text { 1CUN } \\
(7-112)\end{array}$ & 106 & -2.08 & $\begin{array}{c}-1.47 \\
( \pm 0.07)\end{array}$ & $\begin{array}{c}14.44 \\
( \pm 0.45)\end{array}$ & $\begin{array}{c}9.50 \\
( \pm 0.51)\end{array}$ & 32 \\
\hline 1YYJ & 106 & -3.65 & $\begin{array}{c}-1.42 \\
( \pm 0.20)\end{array}$ & $\begin{array}{c}12.45 \\
( \pm 0.33)\end{array}$ & $\begin{array}{c}11.57 \\
( \pm 0.50)\end{array}$ & 56 \\
\hline $\begin{array}{c}2 \mathrm{~J} 5 \mathrm{~A} \\
(3-108)\end{array}$ & 106 & -3.17 & $\begin{array}{c}-0.93 \\
( \pm 0.00)\end{array}$ & $\begin{array}{c}13.00 \\
( \pm 0.00)\end{array}$ & $\begin{array}{c}12.00 \\
( \pm 0.00)\end{array}$ & 6 \\
\hline $\begin{array}{c}1 \mathrm{CUN} \\
(113-219)\end{array}$ & 107 & -1.48 & $\begin{array}{c}-1.19 \\
( \pm 0.29)\end{array}$ & $\begin{array}{c}12.71 \\
( \pm 0.29)\end{array}$ & $\begin{array}{c}11.75 \\
( \pm 0.45)\end{array}$ & 16 \\
\hline $1 \mathrm{D} 6 \mathrm{O}$ & 107 & -0.69 & $\begin{array}{c}-0.68 \\
( \pm 0.28)\end{array}$ & $\begin{array}{c}17.15 \\
( \pm 0.56)\end{array}$ & $\begin{array}{c}8.33 \\
( \pm 0.48)\end{array}$ & 24 \\
\hline $\begin{array}{c}1 \mathrm{BNI} \\
(3-110)\end{array}$ & 108 & -1.17 & $\begin{array}{c}-0.74 \\
( \pm 0.20)\end{array}$ & $\begin{array}{c}17.78 \\
( \pm 0.67)\end{array}$ & $\begin{array}{c}7.60 \\
( \pm 0.50)\end{array}$ & 30 \\
\hline $\begin{array}{c}1 \mathrm{U} 4 \mathrm{Q} \\
(1662-1771)\end{array}$ & 110 & -4.78 & $\begin{array}{c}-0.98 \\
( \pm 0.31)\end{array}$ & $\begin{array}{c}13.42 \\
( \pm 0.26)\end{array}$ & $\begin{array}{c}11.45 \\
( \pm 0.50)\end{array}$ & 66 \\
\hline $\begin{array}{c}1 \mathrm{QAU} \\
(14-125)\end{array}$ & 112 & -0.78 & $\begin{array}{c}-0.96 \\
( \pm 0.36)\end{array}$ & $\begin{array}{c}15.59 \\
( \pm 0.40)\end{array}$ & $\begin{array}{c}9.33 \\
( \pm 0.58)\end{array}$ & 3 \\
\hline $2 \mathrm{KDI}$ & 114 & -1.00 & $\begin{array}{c}-0.49 \\
( \pm 0.30)\end{array}$ & $\begin{array}{c}15.00 \\
( \pm 0.29)\end{array}$ & $\begin{array}{c}10.83 \\
( \pm 0.46)\end{array}$ & 116 \\
\hline $\begin{array}{c}\text { 1QTU } \\
(1-115)\end{array}$ & 115 & 0.16 & $\begin{array}{c}-1.14 \\
( \pm 0.00)\end{array}$ & $\begin{array}{c}14.60 \\
( \pm 0.00)\end{array}$ & $\begin{array}{c}10.00 \\
( \pm 0.00)\end{array}$ & 24 \\
\hline 2MYO & 118 & -2.08 & $\begin{array}{c}-0.55 \\
( \pm 0.87)\end{array}$ & $\begin{array}{c}15.92 \\
( \pm 0.41)\end{array}$ & $\begin{array}{c}9.60 \\
( \pm 0.49)\end{array}$ & 60 \\
\hline $1 \mathrm{HCD}$ & 118 & -0.56 & $\begin{array}{c}-0.48 \\
( \pm 0.00)\end{array}$ & $\begin{array}{c}15.90 \\
( \pm 0.00)\end{array}$ & $\begin{array}{c}10.00 \\
( \pm 0.00)\end{array}$ & 4 \\
\hline 2GA5 & 119 & -2.35 & $\begin{array}{c}-1.12 \\
( \pm 0.53)\end{array}$ & $\begin{array}{c}12.68 \\
( \pm 0.27)\end{array}$ & $\begin{array}{c}11.83 \\
( \pm 0.69)\end{array}$ & 48 \\
\hline $1 \mathrm{EKG}$ & 119 & -1.52 & $\begin{array}{c}-0.88 \\
( \pm 0.23)\end{array}$ & $\begin{array}{c}14.07 \\
( \pm 0.20)\end{array}$ & $\begin{array}{c}11.00 \\
( \pm 0.00)\end{array}$ & 28 \\
\hline $1 \mathrm{ADW}$ & 123 & -0.30 & $\begin{array}{c}-0.99 \\
( \pm 0.10)\end{array}$ & $\begin{array}{c}13.88 \\
( \pm 0.09)\end{array}$ & $\begin{array}{c}11.00 \\
( \pm 0.00)\end{array}$ & 40 \\
\hline $1 \mathrm{~J} 5 \mathrm{U}$ & 124 & -3.00 & $\begin{array}{c}-0.13 \\
( \pm 0.03)\end{array}$ & $\begin{array}{c}15.06 \\
( \pm 0.51)\end{array}$ & $\begin{array}{c}11.50 \\
( \pm 0.53)\end{array}$ & 8 \\
\hline $\begin{array}{c}\text { 1FGA } \\
(20-143)\end{array}$ & 124 & 0.61 & $\begin{array}{c}-0.17 \\
( \pm 0.00)\end{array}$ & $\begin{array}{c}16.50 \\
( \pm 0.00)\end{array}$ & $\begin{array}{c}10.00 \\
( \pm 0.00)\end{array}$ & 4 \\
\hline $\begin{array}{c}5 \mathrm{~L} 8 \mathrm{I} \\
(3-127)\end{array}$ & 125 & -0.28 & $\begin{array}{c}0.70 \\
( \pm 0.00)\end{array}$ & $\begin{array}{c}19.22 \\
( \pm 0.00)\end{array}$ & $\begin{array}{c}9.00 \\
( \pm 0.00)\end{array}$ & 2 \\
\hline $304 D$ & 126 & -2.13 & $\begin{array}{c}0.03 \\
( \pm 0.00)\end{array}$ & $\begin{array}{c}16.90 \\
( \pm 0.00)\end{array}$ & $\begin{array}{c}10.00 \\
( \pm 0.00)\end{array}$ & 10 \\
\hline
\end{tabular}




\begin{tabular}{|c|c|c|c|c|c|c|}
\hline 2VIL & 126 & -1.82 & $\begin{array}{c}-0.20 \\
( \pm 0.00)\end{array}$ & $\begin{array}{c}17.44 \\
( \pm 0.00)\end{array}$ & $\begin{array}{c}9.00 \\
( \pm 0.00)\end{array}$ & 2 \\
\hline 3049 & 127 & -0.74 & $\begin{array}{c}0.39 \\
( \pm 0.00)\end{array}$ & $\begin{array}{c}17.60 \\
( \pm 0.00)\end{array}$ & $\begin{array}{c}10.00 \\
( \pm 0.00)\end{array}$ & 2 \\
\hline $3 \mathrm{CHY}$ & 128 & -0.43 & $\begin{array}{c}-0.19 \\
( \pm 0.11)\end{array}$ & $\begin{array}{c}14.45 \\
( \pm 0.10)\end{array}$ & $\begin{array}{c}12.00 \\
( \pm 0.00)\end{array}$ & 80 \\
\hline $\begin{array}{c}1 \mathrm{HRH} \\
(427-556)\end{array}$ & 130 & -0.38 & $\begin{array}{c}0.27 \\
( \pm 0.16)\end{array}$ & $\begin{array}{c}13.67 \\
( \pm 0.37)\end{array}$ & $\begin{array}{c}13.67 \\
( \pm 0.52)\end{array}$ & 6 \\
\hline $1 \mathrm{IFC}$ & 131 & -1.87 & $\begin{array}{c}0.53 \\
( \pm 0.00)\end{array}$ & $\begin{array}{c}18.89 \\
( \pm 0.00)\end{array}$ & $\begin{array}{c}9.00 \\
( \pm 0.00)\end{array}$ & 4 \\
\hline $\begin{array}{c}\text { 1OPA } \\
(1-133)\end{array}$ & 133 & -0.61 & $\begin{array}{c}0.40 \\
( \pm 0.28)\end{array}$ & $\begin{array}{c}17.35 \\
( \pm 0.75)\end{array}$ & $\begin{array}{c}10.25 \\
( \pm 0.62)\end{array}$ & 12 \\
\hline $1 \mathrm{CBI}$ & 136 & 1.39 & $\begin{array}{c}0.04 \\
( \pm 0.29)\end{array}$ & $\begin{array}{c}13.87 \\
( \pm 0.26)\end{array}$ & $\begin{array}{c}13.00 \\
( \pm 0.00)\end{array}$ & 4 \\
\hline 1RG8 & 137 & -0.56 & $\begin{array}{c}0.22 \\
( \pm 0.25) \\
\end{array}$ & $\begin{array}{c}17.23 \\
( \pm 0.24) \\
\end{array}$ & $\begin{array}{c}10.00 \\
( \pm 0.00)\end{array}$ & 36 \\
\hline $\begin{array}{c}\text { 304B } \\
(11-147)\end{array}$ & 137 & -1.87 & $\begin{array}{c}0.83 \\
( \pm 0.00)\end{array}$ & $\begin{array}{c}17.45 \\
( \pm 0.00)\end{array}$ & $\begin{array}{c}11.00 \\
( \pm 0.00)\end{array}$ & 4 \\
\hline 2FS6 & 137 & -1.00 & $\begin{array}{c}0.41 \\
( \pm 0.50)\end{array}$ & $\begin{array}{c}14.24 \\
( \pm 0.33)\end{array}$ & $\begin{array}{c}13.27 \\
( \pm 0.68)\end{array}$ & 450 \\
\hline $\begin{array}{c}\text { 1NFI } \\
(67-206)\end{array}$ & 140 & -0.78 & $\begin{array}{c}0.64 \\
( \pm 0.17) \\
\end{array}$ & $\begin{array}{c}14.07 \\
( \pm 0.15) \\
\end{array}$ & $\begin{array}{c}14.00 \\
( \pm 0.00)\end{array}$ & 12 \\
\hline $3 \mathrm{H} 08$ & 146 & -0.69 & $\begin{array}{c}0.32 \\
( \pm 0.00)\end{array}$ & $\begin{array}{c}14.46 \\
( \pm 0.00)\end{array}$ & $\begin{array}{c}13.00 \\
( \pm 0.00)\end{array}$ & 32 \\
\hline $\begin{array}{c}3 \text { F6R } \\
(2-148)\end{array}$ & 147 & -1.52 & $\begin{array}{c}0.29 \\
( \pm 0.25) \\
\end{array}$ & $\begin{array}{c}13.57 \\
( \pm 0.14) \\
\end{array}$ & $\begin{array}{c}13.80 \\
( \pm 0.41)\end{array}$ & 15 \\
\hline $\begin{array}{c}2 \mathrm{~A} 5 \mathrm{E} \\
(9-156)\end{array}$ & 148 & -1.52 & $\begin{array}{c}1.15 \\
( \pm 0.20)\end{array}$ & $\begin{array}{c}18.09 \\
( \pm 0.14)\end{array}$ & $\begin{array}{c}10.97 \\
( \pm 0.18)\end{array}$ & 58 \\
\hline $2 \mathrm{PQE}$ & 149 & -0.96 & $\begin{array}{c}1.15 \\
( \pm 0.00)\end{array}$ & $\begin{array}{c}18.09 \\
( \pm 0.00)\end{array}$ & $\begin{array}{c}11.00 \\
( \pm 0.00)\end{array}$ & 4 \\
\hline $1 \mathrm{~K} 0 \mathrm{~S}$ & 151 & -3.21 & $\begin{array}{c}0.56 \\
( \pm 0.31)\end{array}$ & $\begin{array}{c}13.67 \\
( \pm 0.19)\end{array}$ & $\begin{array}{c}14.21 \\
( \pm 0.41)\end{array}$ & 152 \\
\hline $1 \mathrm{~A} 6 \mathrm{~N}$ & 151 & -0.48 & $\begin{array}{c}0.91 \\
( \pm 0.82)\end{array}$ & $\begin{array}{c}15.02 \\
( \pm 0.48)\end{array}$ & $\begin{array}{c}13.40 \\
( \pm 0.85)\end{array}$ & 1924 \\
\hline $\begin{array}{c}1 \mathrm{1IBB} \\
(3-153)\end{array}$ & 151 & 1.74 & $\begin{array}{c}1.01 \\
( \pm 0.00)\end{array}$ & $\begin{array}{c}13.80 \\
( \pm 0.00)\end{array}$ & $\begin{array}{c}15.00 \\
( \pm 0.00)\end{array}$ & 140 \\
\hline $\begin{array}{l}\text { 1DWR } \\
(1-152)\end{array}$ & 152 & -1.26 & $\begin{array}{c}0.77 \\
( \pm 0.07)\end{array}$ & $\begin{array}{c}15.33 \\
( \pm 0.06)\end{array}$ & $\begin{array}{c}13.00 \\
( \pm 0.00)\end{array}$ & 36 \\
\hline 2RN2 & 155 & 0.13 & $\begin{array}{c}1.66 \\
( \pm 0.27)\end{array}$ & $\begin{array}{c}15.56 \\
( \pm 0.32)\end{array}$ & $\begin{array}{c}14.50 \\
( \pm 0.51)\end{array}$ & 24 \\
\hline 1RA9 & 159 & 0.16 & $\begin{array}{c}1.45 \\
( \pm 0.00)\end{array}$ & $\begin{array}{c}14.67 \\
( \pm 0.00)\end{array}$ & $\begin{array}{c}15.00 \\
( \pm 0.00)\end{array}$ & 24 \\
\hline $2 \mathrm{KLL}$ & 160 & 0.61 & $\begin{array}{c}1.41 \\
( \pm 0.52)\end{array}$ & $\begin{array}{c}12.18 \\
( \pm 0.15)\end{array}$ & $\begin{array}{c}17.32 \\
( \pm 0.51)\end{array}$ & 1248 \\
\hline $\begin{array}{c}\text { 1L63 } \\
(1-162)\end{array}$ & 162 & -1.61 & $\begin{array}{c}0.95 \\
( \pm 0.14)\end{array}$ & $\begin{array}{c}15.69 \\
( \pm 0.11)\end{array}$ & $\begin{array}{c}13.00 \\
( \pm 0.00)\end{array}$ & 12 \\
\hline
\end{tabular}




\begin{tabular}{|c|c|c|c|c|c|c|}
\hline $1 \mathrm{LOP}$ & 164 & -2.87 & $\begin{array}{c}1.82 \\
( \pm 0.53)\end{array}$ & $\begin{array}{c}15.62 \\
( \pm 0.36)\end{array}$ & $\begin{array}{c}14.67 \\
( \pm 0.49)\end{array}$ & 18 \\
\hline $\begin{array}{l}\text { 1FTG } \\
(2-169)\end{array}$ & 168 & -1.00 & $\begin{array}{c}2.16 \\
( \pm 0.00)\end{array}$ & $\begin{array}{c}17.07 \\
( \pm 0.00)\end{array}$ & $\begin{array}{c}14.00 \\
( \pm 0.00)\end{array}$ & 2 \\
\hline $\begin{array}{l}\text { 1PHP } \\
(1-175)\end{array}$ & 175 & -1.00 & $\begin{array}{c}1.60 \\
( \pm 0.50)\end{array}$ & $\begin{array}{c}16.71 \\
( \pm 0.56)\end{array}$ & $\begin{array}{c}13.17 \\
( \pm 0.55)\end{array}$ & 768 \\
\hline $\begin{array}{c}1 \text { PHP } \\
(186-394)\end{array}$ & 209 & 1.74 & $\begin{array}{c}3.50 \\
( \pm 0.36)\end{array}$ & $\begin{array}{c}15.42 \\
( \pm 0.21)\end{array}$ & $\begin{array}{c}18.25 \\
( \pm 0.44)\end{array}$ & 96 \\
\hline $1 \mathrm{IO} 2$ & 213 & 0.11 & $\begin{array}{c}2.90 \\
( \pm 0.38)\end{array}$ & $\begin{array}{c}15.42 \\
( \pm 0.08)\end{array}$ & $\begin{array}{c}17.08 \\
( \pm 0.27)\end{array}$ & 78 \\
\hline $\begin{array}{c}\text { 1IGS } \\
(27-248)\end{array}$ & 222 & 1.95 & $\begin{array}{c}3.70 \\
( \pm 0.52)\end{array}$ & $\begin{array}{c}14.25 \\
( \pm 0.27)\end{array}$ & $\begin{array}{c}19.75 \\
( \pm 0.67)\end{array}$ & 32 \\
\hline $\begin{array}{c}\text { 1UCH } \\
(5-230)\end{array}$ & 226 & 1.13 & $\begin{array}{c}5.09 \\
( \pm 0.78)\end{array}$ & $\begin{array}{c}13.91 \\
( \pm 0.21)\end{array}$ & $\begin{array}{c}22.67 \\
( \pm 0.85)\end{array}$ & 480 \\
\hline $\begin{array}{c}\text { 1B9C } \\
(4-230)\end{array}$ & 227 & 1.13 & $\begin{array}{c}4.17 \\
( \pm 0.71) \\
\end{array}$ & $\begin{array}{c}16.68 \\
( \pm 0.27) \\
\end{array}$ & $\begin{array}{c}18.10 \\
( \pm 0.70)\end{array}$ & 80 \\
\hline $1 \mathrm{THF}$ & 253 & 1.39 & $\begin{array}{c}5.42 \\
( \pm 0.50)\end{array}$ & $\begin{array}{c}15.05 \\
( \pm 0.41)\end{array}$ & $\begin{array}{c}22.33 \\
( \pm 0.47)\end{array}$ & 288 \\
\hline 3BLM & 257 & 2.87 & $\begin{array}{c}5.71 \\
( \pm 0.25)\end{array}$ & $\begin{array}{c}16.28 \\
( \pm 0.17)\end{array}$ & $\begin{array}{c}21.75 \\
( \pm 0.43)\end{array}$ & 640 \\
\hline 1V9E & 259 & 1.91 & $\begin{array}{c}5.41 \\
( \pm 0.21)\end{array}$ & $\begin{array}{c}16.44 \\
( \pm 0.19) \\
\end{array}$ & $\begin{array}{c}21.00 \\
( \pm 0.00)\end{array}$ & 72 \\
\hline $\begin{array}{c}\text { 4BLM } \\
(31-291)\end{array}$ & 261 & 2.04 & $\begin{array}{c}5.25 \\
( \pm 0.31)\end{array}$ & $\begin{array}{c}15.43 \\
( \pm 0.21)\end{array}$ & $\begin{array}{c}21.67 \\
( \pm 0.47)\end{array}$ & 144 \\
\hline 1WQ5 & 268 & 0.91 & $\begin{array}{c}5.57 \\
( \pm 0.15) \\
\end{array}$ & $\begin{array}{c}14.88 \\
( \pm 0.16) \\
\end{array}$ & $\begin{array}{r}22.89 \\
( \pm 0.32) \\
\end{array}$ & 72 \\
\hline $\begin{array}{c}1 \mathrm{~L} 8 \mathrm{~W} \\
\text { (Chain B: 29-335) }\end{array}$ & 307 & -0.87 & $\begin{array}{c}7.74 \\
( \pm 0.87)\end{array}$ & $\begin{array}{c}15.46 \\
( \pm 0.21)\end{array}$ & $\begin{array}{c}26.35 \\
( \pm 0.82)\end{array}$ & 241920 \\
\hline
\end{tabular}




\section{L] Calculated folding times using $<N_{\text {blob }}>$ and $<n_{\mathrm{b}}>$ :}

The averaged folding time $\left\langle\tau_{\mathrm{F}}>\right.$ of the proteins presented in the main text was determined by averaging the $\tau_{\mathrm{F}}$ values calculated for each possible string of blobs obtained from a systematic search of the protein sequence. Since it was not possible to report all the sets of $N_{\mathrm{blob}}$ and $n_{\mathrm{b}}$ values obtained through this analysis, all $N_{\text {blob }}$ and $n_{\mathrm{b}}$ values were averaged to yield the $<N_{\text {blob }}>$ and $\left\langle n_{\mathrm{b}}>\right.$ values for a specific protein, and $\left\langle N_{\mathrm{blob}}>\right.$ and $\left\langle n_{\mathrm{b}}>\right.$ were listed in Table S6. Incidentally, the $\tau_{\mathrm{F}}$ values calculated by applying these $<N_{\text {blob }}>$ and $<n_{\mathrm{b}}>$ values into Equation S11 were as strongly correlated with the experimental $\tau_{\mathrm{F}}$ values as the $\left\langle\tau_{\mathrm{F}}>\right.$ values obtained in the main text in Figure 9. In fact, the trends were almost identical as can be seen by comparing Figures S6A and S6B.

$$
\tau_{F}=\Omega\left(<N_{b l o b}>\right) \times \Omega\left(<n_{b}>\right) \times \tau_{p}
$$
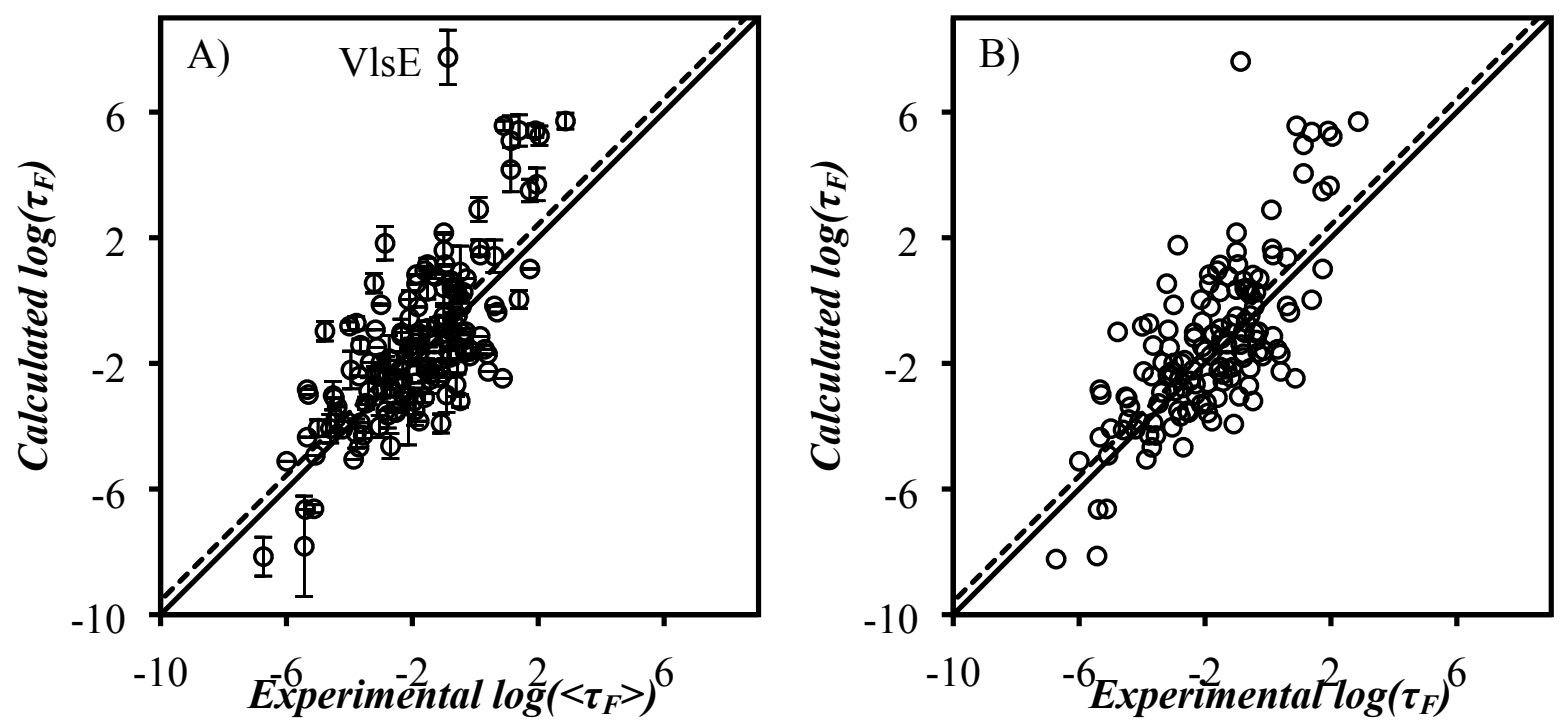

Figure S6. Plots of the logarithm of the folding time $\left(\tau_{\mathrm{F}}\right)$ of proteins calculated by A) averaging the $\tau_{\mathrm{F}}$ values for each string of blobs and B) using the average $<N_{\mathrm{blob}}>$ and $<n_{\mathrm{b}}>$ values of all strings of blobs (Equation S11). 


\section{M] References}

1. Li, L.; Duhamel, J. Conformation of Pyrene-Labeled Amylose in DMSO Characterized with the Fluorescence Blob Model. Macromolecules 2016, 49, 7965 - 7974.

2. Muñoz, V.; Thompson, P. A.; Hofrichter, J.; Eaton, W. A. Folding Dynamics and Mechanism of $\beta$-hairpin Formation. Nature 1997, 390, 196 - 199.

3. Manavalan, B., Kuwajima, K.; Lee, J. PFDB: A standardized Protein Folding Database with Temperature Correction. Sci. Rep. 2019, 9, 1588.

4. Garbuzynskiy, S. O.; Ivankov, D. N.; Bogatyreva, N. S.; Finkelstein, A. V. Golden Triangle for Folding Rates of Globular Proteins. Proc. Natl. Acad. Sci. U. S. A. 2013, 110, 147 - 150. 